Article

\title{
Beyond Rewards and Punishments in the Brazilian Amazon: Practical Implications of the REDD+ Discourse
}

\author{
Maria Fernanda Gebara ${ }^{1, *}$ and Arun Agrawal ${ }^{2}$ \\ 1 Development, Agriculture and Society Institute, Federal Rural University of Rio de Janeiro, \\ Rio de Janeiro 20.071-003, Brazil \\ 2 School of Natural Resources and Environment, University of Michigan, Ann Arbor, MI 48109, USA; \\ arunagra@umich.edu \\ * Correspondence: mfgebara@gmail.com; Tel.: +44-789-456-9543
}

Academic Editors: Esteve Corbera and Heike Schroeder

Received: 13 November 2016; Accepted: 27 February 2017; Published: 2 March 2017

\begin{abstract}
Through different policies and measures reducing emissions from deforestation and degradation and enhancing conservation (REDD+) has grown into a way to induce behavior change of forest managers and landowners in tropical countries. We argue that debates around REDD+ in Brazil have typically highlighted rewards and punishments, obscuring other core interventions and strategies that are also critically important to reach the goal of reducing deforestation, supporting livelihoods, and promoting conservation (i.e., technology transfer and capacity building). We adopt Foucault's concepts of governmentality and technologies of governance to provide a reading of the REDD+ discourse in Brazil and to offer an historical genealogy of the rewards and punishments approach. By analyzing practical elements from REDD+ implementation in the Brazilian Amazon, our research provides insights on the different dimensions in which smallholders react to rewards and punishments. In doing so, we add to the debate on governmentality, supplementing its focus on rationalities of governance with attention to the social practices in which such rationalities are embedded. Our research also suggests that the techniques of remuneration and coercion on which a rewards and punishments approach relies are only supporting limited behavioral changes on the ground, generating negative adaptations of deforestation practices, reducing positive feedbacks and, perhaps as importantly, producing only short-term outcomes at the expense of positive long-term land use changes. Furthermore, the approach ignores local heterogeneities and the differences between the agents engaging in forest clearing in the Amazon. The practical elements of the REDD+ discourse in Brazil suggest the rewards and punishments approach profoundly limits our understanding of human behavior by reducing the complex and multi-dimensional to a linear and rational simplicity. Such simplification leads to an underestimation of smallholders' capacity to play a key role in climate mitigation and adaptation. We conclude by highlighting the importance of looking at local heterogeneities and capacities and the need to promote trust, altruism and responsibility towards others and future generations.
\end{abstract}

Keywords: REDD+; Amazon; discourse; genealogy; rewards and punishments; behavior change

\section{Introduction}

During the past decade, the "carrots and sticks" approach has emerged as a combination of rewards (i.e., financial incentives) and punishments (i.e., penalties) to influence behavioral change toward reducing emissions from deforestation and degradation and enhancing conservation (REDD+) [1-7]. By undertaking a discourse analysis and drawing on practical elements of REDD+ 
implementation, this article explores how the rewards and punishments approach has been used to legitimize techniques of governance in the Brazilian Amazon. This analysis builds on Foucault's important contributions related to the analysis of power and knowledge [8], and is therefore critical. But rather than a complete recapitulation and elaboration of the arguments for or against rewards and punishments as the way to implement REDD+, we focus on what the current debate on REDD+ in Brazil tends to marginalize and set aside. Little if any of the work on REDD+ is attentive to insights from Foucault's work or to the kinds of analytical directions that studies related to governmentality open and make available. Our contribution, thus, is primarily a theory-building effort and it is critical in its explicit attempt to turn what is not presently conceived of as being problematic into something that is necessary to consider [9]. Our main hypothesis is that the REDD+ discourse in Brazil is making only certain things (rewards and punishments) visible, obscuring the importance of other core interventions for REDD+, such as measures focused on knowledge sharing, collective resilience, recognition of rights, technology transfer, and social and technical capacity building and development, to name a few key issues.

Since 2007, REDD+ has grown into a policy instrument to reduce deforestation in many tropical countries, with implementation occurring at local to national scales. Even as REDD+ interventions have evolved along different pathways, with many initiatives largely fulfilling roles as pilot projects, most are struggling to make a transition to sustained larger-scale success [10]. The Brazilian Amazon, which houses the largest remaining expanse of tropical forests, is a major focus of REDD+ implementation because of the country's successes in reducing deforestation. These successes can be attributed mainly to centralized command and control efforts (i.e., monitoring and law enforcement) but also to changes in relative prices of agricultural commodities [11-13]. However, recent evidence also shows command and control efforts in the Amazon have had heterogeneous effects, highlighting the need to adapt forest conservation measures to regional specificities [14]. Deforestation trends have also changed; once driven by large-scale clear-cutting, forest clearing in the Amazon now occurs mostly in small areas $[15,16]$. These trends have attracted the attention of the Brazilian national government to the role smallholders play in deforestation. In this paper, we focus on smallholders in particular to undertake a close reading of the rewards and punishments discourse and practice in Brazil. We also offer an historical genealogy of the approach to improve our understanding of the direction in which it is heading.

The study of policy interventions and governance tends to occur in a discursive field in which the exercise of power is "rationalized". Strategies through which such rationalization of political underpinnings and motivations occurs include the delineation of concepts, the specification of objects and borders, an emphasis on identifying models of individuals and their behaviors, and the development of arguments and justifications that naturalize observed actions and responses. Such efforts to analyze policy interventions, governance (and responses to governance interventions) portray inherently political problems as technical, and equally political actions and interventions as technical, common-sense solution strategies. They structure "a field of possibilities in which several ways of behaving, several reactions and diverse comportments, may be realized" [9]. In this structuring of the large field of possibilities, interventions and responses that do not correspond to dominant models of policy making and corresponding behavior are rendered as irrational or non-systematic and the goal of policy analysis shifts into a more normative register where the irrational and non-systematic can either be ignored or needs to be rationalized. Foucault's analyses thus provide a useful starting point and valuable insights into the different dimensions of the arts of government as ways of defining, knowing, and improving outcomes. His contributions focus on the rationality of government, meaning a way of thinking about the nature and the practice of government (who can govern; what or who is governed; how governance happens; why particular modes of governance are necessary or to be defended; and the like). We build on his work by looking into the different relationships between the governed and governing and how these relationships unfold. 
Our analysis draws from the experience of six different REDD+ initiatives in Brazil. It aims at a different-compared to much of the prevailing models of REDD+ and payments for ecosystem services more generally-way of understanding the implications of categorizing REDD+ interventions into techniques of remuneration and coercion on which rewards and punishments rely. Important questions include: (a) What does the rewards and punishments discourse highlight? (b) What does this same discourse obscure from consideration? (c) What kind of subjects does it assume in practice, and through its efforts at implementation, also produce? (d) Is the assumed subject sufficiently realized for REDD+ to be effective? And, finally (e) Is the rewards and punishments discourse justifiable for REDD+? The analysis rests upon an application of Foucault's genealogical approach to some of the key underpinnings of the rewards and punishments approach (Section 2). Section 3 consists of a brief discussion of our methods and the next section hones in on the practical relevance of a Foucault-inspired approach in relation to REDD+ interventions in the Brazilian Amazon (Section 4). In Section 5 we discuss the implications of our findings for REDD+ implementation. Our analysis suggests that the techniques of remuneration (i.e., rewards) and coercion (i.e., punishments) lead to heterogeneous and at best only limited behavioral shifts on the ground, often prompting negative adaptations of deforestation practices, limiting and reducing positive feedbacks and, just as importantly, possibly producing only short-term changes at the expense of positive longer-term land use changes. In its search for a global model relevant to deforestation reduction, the approach ignores local heterogeneities and differences among agents involved in forest clearing. These findings constitute evidence that confirms our starting hypothesis: the exclusive attention to conditions conducive to the success of a rational system of rewards and punishments has led to the neglect of other forms of REDD+ interventions that may be more effective. These findings also suggest that a preoccupation with a rational rewards and punishments arrangement profoundly constrains the understanding of the multiplicity of human choices and behaviors by reducing a complex and multi-dimensional set of experiences into a linear and rational simplicity. Moreover, the approach underestimates the capacities of the very smallholders that are expected to and can play a key role in climate mitigation and adaptation. We conclude by highlighting the importance of attending to local heterogeneities, strengthening diverse capacities, and promoting trust, altruism and responsibility towards others and future generations.

\section{Opening up the Rewards and Punishments Discourse}

\subsection{Foucault's Genealogy}

In an attempt to open up the rewards and punishments discourse, we offer an historical genealogy of the approach to show how we arrived at this technique of governance to induce new behaviors, and what its practices conceal. In its ordinary sense, genealogy is synonymous with the study of one's ancestors, or in Foucault's words: "the history of the present" [8]. In a more specific sense, genealogy is a Nietzschean expression used for reconstructing a term by establishing genealogical charts of linked conceptual fragments and relationships. Examining the genealogical nature of the rewards and punishments discourse is necessary to understand the systematic ways in which colonial countries such as Brazil manage and control their forests and, in many ways, even create the knowledge and subjects of their governance in political, economic, sociological and cultural systems. The ensemble of governance practices includes a whole series of national efforts (often promoted by the discourses of Western countries and actors that are being set up on a global scale) that constitute one of the most powerful mechanisms to ensure control over the people living in forested territories. Policy instruments—such as rewards and punishments—can be viewed here as part of the evolving "set of techniques by which governmental authorities wield their power in attempting to ensure support and effect social change" [17]. Practices of government in a Foucauldian sense comprise both technologies of control and (cor)responding technologies of subject making on the part of those at whom the technologies of control are directed. 
According to Foucault, the deployment of technologies of control—and subject making-rest on power which should be viewed not as something that is stratified or as an object, but as capacities diffused throughout the social body. One cannot have power; rather, power is manifested in its exercise; thus, power is everywhere, but unevenly distributed [18]. As Foucault states, "each society has its regime of truth, its "general politics" of truth: that is, the types of discourse which accepts and makes function as true; the mechanisms and instances which enable one to distinguish true and false statements, the means by which each is sanctioned; the techniques and procedures accorded value in the acquisition of truth; the status of those who are charged with saying what counts as true" [19]. The relationship between content, expression, power-relations and material practices forms discourses, which are "systems of thoughts composed of ideas, attitudes, courses of actions, beliefs and practices that systematically construct the subjects and the worlds of which they speak. He traces the role of discourses in wider social processes of legitimation and power, emphasizing the constitution of current truths, how they are maintained and what power relations they carry with them" [20]. We build on these Foucauldian insights into discursive analysis with a focus on the productive aspects of discourses, meaning "the practices they (discourses) invoke" [21].This focus on practices is important to understand what the rewards and punishments discourse is making visible, what it is obscuring, what subjects it is producing and if these subjects are sufficiently realized for REDD+ to be effective.

Two concepts used by Foucault become important in interrogating the rewards and punishments discourse: the techniques of disciplinary power and governmentality. Discipline is first and foremost a multifaceted and local technique to target the behavior of individuals in specific settings: "Discipline may be identified neither with an institution nor with an apparatus; it is a type of power, a modality for its exercise, comprising a whole set of instruments, techniques, procedures, levels of application, targets" [8]. Foucault makes explicit what discipline entails as a practice of shaping and modifying conducts to impose ends or execute overall strategies. Foucault's argument is that discipline creates "docile bodies" [8], ideal for the new economics, politics and warfare of the modern industrial age-bodies that function in factories, ordered military regiments, and school classrooms. But, to construct docile bodies, the disciplinary institutions must be able to (a) constantly observe and record the bodies they control and (b) ensure the internalization of the disciplinary individuality within the bodies being controlled. That is, discipline must come about without excessive force through careful observation, and molding of the bodies into the correct form through this observation [8].

Later, in an attempt to study the art of governing, the reasoned way of governing best and, at the same time, reflecting on the best possible ways of governing, Foucault coined a new term to capture the combination of "government" and "rationality": "governmentality." Foucault depicted "governmental rationality" through his understanding of the term "government" as having both a wide and a narrow sense. He proposed a definition of "government" in general as meaning "the conduct of conduct": that is to say, a form of activity aiming to shape, guide or affect the conduct of some persons or agents [22]. Government as an activity could concern the relations between self and self, private interpersonal relations involving some form of control or guidance, relations within social institutions and communities and, certainly, relations concerned with the exercise of political sovereignty as well. Governmentality then is also embodied in routine action and normative orientations, and is about making rational certain forms of exercise of power in preference to others. Thus, governmentality is about making things visible, in a certain, governable way; state government is not only a material structure and a mode of thinking, but also a lived and embodied experience, a mode of existence [23,24].

Smallholders have been left in a pervasive condition of vulnerability. Historically embedded processes have left lasting legacies in rural governmentality, creating what has been called "green governmentality" [25] and "environmentality" [26], whereby "the environment" is constructed in relation to the exercise of power and control. As argued by Fairhead et al. [27], these long-run historical processes provide a vital set of conditions of possibility-meaning the set of factors and relations that give discourses a sense-which those seeking to profit from the new commoditization of nature have been able to inhabit. The authors argue that "such contemporary dynamics of appropriation of nature 
involve new (re)configurations of actors and relationships; the reinvention of regulatory processes and the construction of novel justificatory discourses" [27].

In the Brazilian Amazon, policies historically determined by paternalistic relationships, military regiments and the substantial presence of local elites [28] strongly limit the ability of smallholders to successfully develop their own initiatives [29-31]. Forest governance in Brazil is still oriented by a development model that looks to global commodity markets and well-qualified entrepreneurs with the necessary capital for large-scale investments. This orientation continues despite a growing consensus about its negative ecological consequences, social impacts, and economic risks [32,33]. We draw upon these contextual conditions and ideas to analyze the practical elements from REDD+ implementation and how smallholders respond to rewards and punishments. By doing so, we move from the conventional focus in debates on governmentality on the rationalities of government to the social practices in which these rationalities are embedded.

\subsection{The Genealogy of Rewards and Punishments}

In the rewards and punishments approach, policy instruments might be formulated either in the positive sense of prescription or encouragement of actions through the creation of positive incentives (such as cash transfers), or in the negative sense of prohibition of actions through the application of penalties. These positive or negative strategies can be used to promote behaviors viewed as desirable by decision makers or inhibit behaviors deemed undesirable [34]. This distinction has its roots in conventional dual divisions between the rewards and punishments or benefits and costs. Incentives include a variety of economic and facilitative measures (not just those based on money). Penalties, on the other hand, are sanctions that involve unpleasant consequences imposed by a legally constituted authority for violation of the law [35].

However, when following Foucault's arguments, it is crucial to understand what is justifiable. We thus view both rewards and punishments as active interventions into the social field (intended to structure the fields of possible actions for determined subjects). In this sense, rewards and punishments may even be viewed as a false distinction, because both require action. Although interventions, in principle, are open to many forms of definitions and interpretations, they all rely on and constitute a particular conception of state sovereignty. The relationship works both ways. Just as interventions require sovereignty to be effective, so also sovereignty is affirmed through the implementation of interventions. This means that when leaders and decision makers justify a given intervention they are simultaneously (re)producing what is to be understood by state sovereignty. By doing so, they are granting specific authorities and competencies, while stripping away others.

\subsubsection{Command and Control}

The term "command and control" is based on the coercive aspects of regulation. It refers to the insurance of rules, orders, norms and provisions of an obligatory nature backed by negative sanctions or threats of negative sanctions (e.g., fines, imprisonment) by the state. The defining property of command and control is that the relationship is authoritative and based in a hierarchy system [36], meaning that the controlled persons or groups are obligated to act in the way stated by the controllers. The origins of command and control stem from the Machiavellian idea [37] of acquisition and maintenance of political power. Machiavelli saw a way to maintain monocentric political power through command and control. His ideas were further supported by Hobbes and his social contract. Both philosophers believed in the inherent selfishness of the individual. It was necessarily this belief that led them to adopt a strong central power-or the "Leviathan," in Hobbes words—as the only means of preventing the disintegration of the social order. Hardin's version of the tragedy of the commons [38] is a clear example of this Hobbesian logic playing out in the governance of natural resources.

Until recently, policy instruments for forest conservation around the world have been largely based in the rationality of command and control policies, meaning the creation of protected areas, restricting, monitoring and controlling land use and law enforcement, and enforcing compliance. The rise of 
command and control follows the military model of civil defense adopted by the United States after the Second World as the primary form of disaster response. In recent decades, however, many authors have pointed out fundamental limits to the regulatory system based on command and control structures. These limits become even more evident when dealing with the increasing recognition of the complexity of objects such as forest landscapes, constituted by non-linear processes, heterogeneous subjects, and inherently difficult to comprehend feedbacks related to social and biophysical interactions [39-43]. Command and control systems implicitly assume their targets to be objects that are relatively simple, clearly definable, and generally linear with respect to cause and effect. This approach has been criticized for being monocentric, authoritative, bureaucratic, unnecessarily intrusive, with high, uneven administrative costs, as well as outdated, limited innovation fraught with implementation problems $[5,44,45]$.

Aldisert and Helms emphasize that "the imagination and interests of individuals cannot thrive in command and control structures." Instead, they argue that it is necessary to have "an environment in which all are committed to a common goal" [46]. Holling and Meffe claim that the adoption of command and control as a forest conservation measure resulted in a pathology that undermines resilience in the long run [47]. Finally, the effectiveness of command and control structures is normally associated with its legitimacy. Command and control approaches are effective in changing behavior as long as there is social consensus around the policy underlying the coercive instrument, and the capacity of the state to ensure compliance. The majority of tropical countries are still developing this ability to create consensus among different social actors, but more importantly, are also still improving their governance capacity.

\subsubsection{Economic Instruments}

Economic tools, in contrast, leave the subjects of governance a certain space within which to choose whether to take an action and indeed to determine the level and intensity of action taken. Or, in Foucault's words, they assume "a minimally 'free' subject" [9]. They neither prescribe nor prohibit the actions to be taken, but make them less (in the case of incentives) or more (in the case of disincentives) expensive. Here we concentrate on positive incentives, as they correspond to the ones linked to REDD+ implementation [48]. In the positive case, a material resource is handed to the agent (e.g., through cash transfers, grants, subsidies or loans), whereas in the negative case the individual or organization is deprived of some material resource (e.g., through taxes, charges or fees).

The term 'incentive' first made its appearance among American engineers in the 1880s and 1890s. It was introduced as a motivational term (or inducement), that had a strong monetary connotation. Of course, the actual use of this specific method of remuneration was not born out of a late nineteenth-century debate. Karl Marx, for one, dated the practice of paying by the piece back to the fourteenth century, serving the basic purpose of exploiting the power of labor [49]. The emergence of economic science in the eighteenth century, however, marked a turning point in the history of governmentality. Just like "the state" was central to the project of the reason of state, so "the market" became a central political and epistemological object in the formation of a distinct, liberal art of governing. A rational and self-interested individual then emerged from different economists' discourses (Francois Quesnay, Adam Smith, Robert Malthus and David Ricardo, for example) based on John Locke's Second Treatise of Government [50]. It was precisely the "alleged rationality and self-interestedness of all individuals that made them governable because it made them respond to changes in their environment in a systematic and predictable way" [22].

This rationalist mode of thought has yielded some interesting insights and results. However, it also underestimates the context in which "real individuals" come to decisions and the multitude of factors shaping decision making. It has already been argued that certain modes of valuing things can be entirely inappropriate. Anderson [51] and Sandel [52], for instance, highlight that "any attempt to commodify a good may corrupt it" and "can even make its very existence impossible." Indeed, research in areas like behavioral economics undermines the idea of a simplistic rational subject, 
pointing to the possibility of motivational crowding whereby material incentives for socially or environmentally desirable actions may have the effect of undermining and reducing the incidence of such actions [53]. The use of economic incentives for forest conservation has been supported since the late 1990s in a number of international and national contexts (e.g., Convention on Biological Diversity; United Nations Environment Programme; and the Sloping Lands Conservation Program in China). Since the emergence of the "ecosystem services" concept, notably used in the Millennium Ecosystem Assessment and the Economics of Ecosystems and Biodiversity processes between 2005 and 2010, economic incentives for supporting environmentally positive actions have been seen as innovative policy tools for biodiversity conservation worldwide [54]. This is part of a common contemporary shift in both ecological and economic spheres wherein "nature" is being consolidated as "natural capital" and the functions of natural systems as ecosystem services. Previously distinct domains (economics and finance vs. ecology and conservation) are coming together in an emerging "green economy" that connects actors, institutions and calculative technologies through specific discourses of rational action and behavior. These discursive shifts underpin the creation of markets for ecosystem services, including for carbon, and are critical in constituting and normalizing the logic of REDD+ [55] (see Figure 1a).
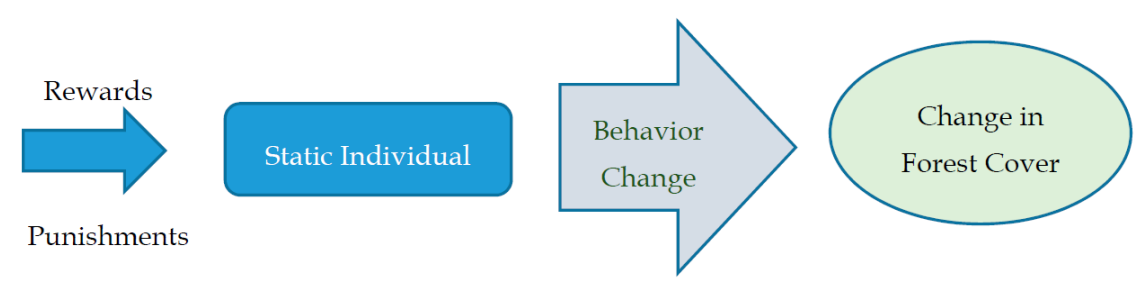

(a)

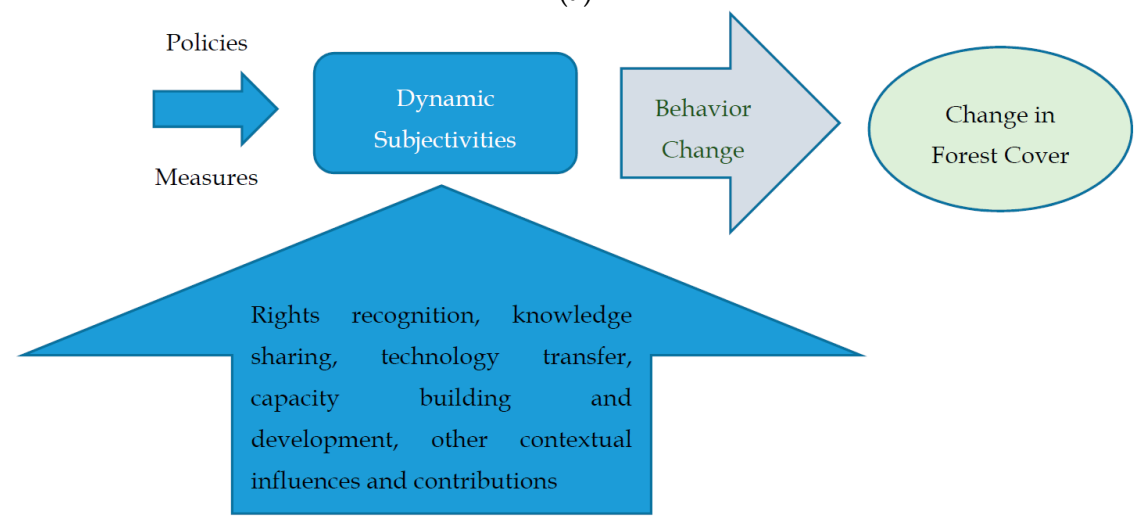

(b)

Figure 1. (a) Conceptual model of the rewards and punishments approach for REDD+ (reducing emissions from deforestation and degradation and enhancing conservation); (b) Conceptual representation of a governmentality approach for REDD+. Legend: The conventional conceptual model underpinning REDD+ assumes an individual that remains consistent in his/her subjectivity over time, responds positively (negatively) to rewards (punishments), and whose behavioral change leads to the desired outcome of increased forest cover. In contrast, as depicted in Figure 1b, a governmentality approach directs attention towards shifts in individual subjectivities, influenced in part by policies and measures that can include rewards and punishments but not necessarily in the desired direction, and with substantial uncertainties in outcomes as a result of variations in recognition of rights, shared knowledge and understandings, technical support, available capacities, and other context specific characteristics.

Although rewards can be used to support forest conservation, they come with restrictions that hinder effectiveness. These include the difficulty of measuring and valuing forest assets, institutional constraints, uncertain, ill-defined, and insecure property rights, ideological resistance, administrative 
complexity, and limited capacity for calculation and implementation [56-65]. The most common approach for incentives as a type of reward are payments for ecosystems services (PES). Economic arguments in favor of incentive-based policy instruments have a strong focus on cost-efficiency, normally defined as use of natural resources to optimize the production of ecosystems goods and services by equating marginal costs and benefits. The rush to confer multi-domain positive valence on such interventions by focusing on win-win or even win-win-win rhetoric can obscure negative side effects [66]. Existing research has demonstrated that financial rewards can crowd out intrinsic motivations $[67,68]$. Gneezy et al., for example, emphasize that the effects of extrinsic incentives depend on how they are designed, the form in which they are delivered (especially monetary or non-monetary), who receives them, knowledge about their distribution, and their interactions with intrinsic motivations [69] (see Figure 1b).

\section{Methods}

Our methods include the review of writings on REDD+ and forest governance to reconstruct the discursive field around deforestation and forest conservation, and empirical evidence from six REDD+ initiative sites in the Brazilian Amazon. The empirical methods used to compile this data are described in Sills et al. [70] in the evaluation of initial impacts of REDD+ that occurred under the Global Comparative Study (GCS) on REDD+, coordinated by the Center for International Forestry Research (CIFOR). The six REDD+ initiatives on which this paper focuses are: (i) the Sustainable Settlements Acre's State System of Incentives for Environmental Services (SISA); (ii) the Bolsa Floresta Program in Amazonas; (iii) the Cotriguaçu Sempre Verde in Mato Grosso; (iv) the Jari REDD+ project in Amapá; (v) the Sustainable Landscapes Pilot Program in São Félix do Xingu and (vi) the Sustainable Settlements initiative in the Transamazon (Figure 2). This research used a variety of data collection techniques, including: quantitative surveys to understand land use, measure subsistence, and learn about the tenure situation, socioeconomic context and the challenges, needs and perceptions (i.e., hopes and worries in relation to REDD+; definitions of local wellbeing) of smallholders. We define property size using the National Agrarian Institute (INCRA) classification, which classifies properties in the Amazon smaller than 300 hectares (or 1-4 fiscal modules) as "small." We also used the "Proponent Appraisal Form" to compile data on the initiatives and on the interventions being implemented. A "Survey of Project Implementation" helped gain insights into the background, history, institutional dynamics and politics surrounding the development of the initiatives. This also served to understand the challenges faced by proponents.

These six sites were selected to include a variety of areas (i.e., private and public), scale (i.e., municipality, state), proponents (i.e., non-governmental organizations (NGOs), public, private) and local actors (i.e., smallholders, large landholders, settlers). In each site, four communities were selected according to GCS methods and around 120 households in each community were randomly selected to be part of the survey. Smallholders' characteristics vary across sites in terms of socioeconomic standards, tenure, community organization, access to markets and wellbeing. More information on methods, proponents, strategies and locations can be found in Sills et al. 2014 [70] and Sunderlin et al. 2016 [71], along with extensive analysis of how REDD+ implementation affects different groups of smallholders.

We also used qualitative data collected in three of the six initiatives: SISA $(2010,2014)$, Bolsa Floresta Program (2009, 2011, 2015) and the Sustainable Landscapes (2010-2014). In these sites, we applied additional methods: (i) observation; (ii) open-ended questions; and (iii) focus groups. Data collection concentrated on understanding how smallholders' behavior is being shaped by the different REDD+ measures. Questions focused on smallholders' perceptions about the initiatives, including: positive and negative aspects of interventions being implemented, suggestions on how to improve them, and what would be necessary to change their practices that cause deforestation. We also conducted open-ended and semi-structured interviews with other relevant stakeholders in the sites (i.e., government actors and NGOs representatives) to capture diverse views of the initiatives and the 
measures being implemented to reduce deforestation. Results, therefore, are based on perceptions of REDD+ actors on ground: the recipients of interventions, but also those who were involved in REDD+ implementation (i.e., proponents and public actors). Analytical coding procedures were applied to produce a coherent analysis focused on the research questions [72]. NVivo Qualitative Content Analysis Software (QSR International Pty Ltd. Version 10, 2012) was chosen to compile, analyze, organize and reconfigure the data collected. A content analysis was then carried out, involving the use of analytical codes derived from existing theories and explanations relevant to the research focus. For a better understanding of the data collected, local perceptions were initially codified in positive and negative aspects of REDD+ measures and in challenges and needs for REDD+ implementation on the ground. After this first codification, the perceptions were codified again to understand practical aspects of governmentality, subjectivity and behavior change. Finally, we reviewed policy, programs and project documents, including the REDD+ National Strategy.

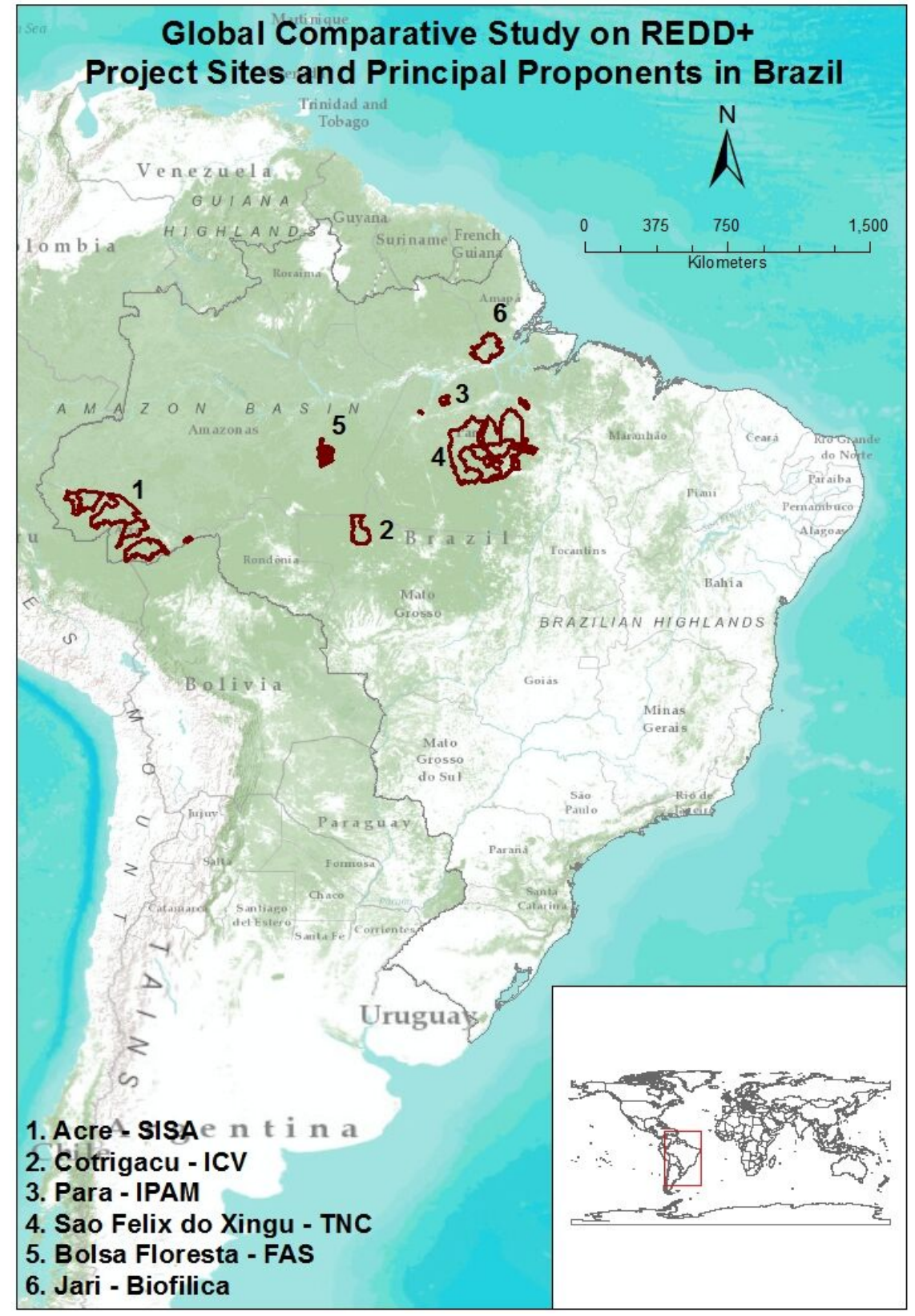

Figure 2. REDD+ initiatives analyzed. 


\section{Results: Rewards and Punishments in Practice}

\subsection{Main REDD+ Strategies in Brazil}

Command and control measures have significantly curbed deforestation in Brazil in recent years. Between 2004 and 2016, the annual deforestation rate in the Brazilian Amazon fell by 71\% [73]. Brazil has also taken significant steps toward setting targets and developing interventions for REDD+, including the construction of a National REDD+ Strategy [74]. There are also numerous sub-national initiatives in the Amazon, ranging from state government programs to private projects [70]. Persistent concerns, however, have been raised about the potential impacts of REDD+ on local livelihoods and socioeconomic welfare $[75,76]$. These impacts depend in part on the particular interventions and safeguards used to achieve REDD+. At the same time, REDD+ is a dynamic arena of negotiation with competing discourses, including those surrounding equitable benefit-sharing, financing, monitoring, indigenous peoples, landscape approaches and others (see for example [77]).

The Brazilian REDD+ national strategy has as its main guiding policies the National Policy for Climate Change and the Forest Code. It also identifies three sectorial plans as the primary channels for implementing REDD+ in Brazil: the Action Plan to Prevent and Control Deforestation in the Amazon (PPCDAm); the Action Plan to Prevent and Control Deforestation and Fire in the Brazilian Cerrado (PPCerrado) and the Plan for Low Carbon Agriculture (ABC). It supplements these plans with cross-cutting measures, including a financial architecture for REDD+ and a set of safeguards designed to ensure that REDD+ actions do not inflict social or environmental harm. Safeguards are based on social and environmental principles and criteria for REDD+ developed in 2010 by a group of civil society organizations. The REDD+ national strategy safeguard summary, however, received much criticism from the civil society and groups involved in the development of safeguards. One of the main issues is that federal safeguards only cover initiatives financed by the Amazon Fund and are related to PPCDAm implementation [78].

Additionally, the national strategy is still very unclear in terms of the types of measures it will concentrate on to implement REDD+ and to guarantee that safeguards are in place. Detailed regulation of these issues was left to the National REDD+ Entity and its Thematic Consultation Chambers, which are still in the incipient stages of designing specific measures and principles. Although participation has been historically recognized as important for strengthening forest governance in Brazil [79], the participation, consultation and representation of local populations and landowners have been highly uneven and in some cases absent [80-83].

Following the REDD+ national strategy, we define REDD+ interventions as those which are linked to the implementation of the policies and plans that guide the strategy. These involve a mix of strategies that in theory should go beyond rewards and punishments, including: tenure regularization (i.e., provision of land titles and tenure clarification), territorial management (i.e., implementation of the Rural Environmental Registry (CAR in Portuguese)), monitoring (i.e., surveillance), enforcement (i.e., application of sanctions and penalties), financial incentives for sustainable production (i.e., sustainable rural credits), PES (i.e., direct cash transfers), improvement of agricultural and livestock practices (i.e., crop-livestock-forestry integration) and environmental education (i.e., capacity building) [74]. While reviewing the initiatives, we found that in the readiness phase (between 2008 and 2015), most of them focused on (i) increasing command and control through surveillance and in situ monitoring and (ii) territorial management through the implementation of the Rural Environmental Registry (CAR), a tool to increase environmental compliance, and enforced nationally by the Forest Code. Other main interventions being implemented include: (iii) PES; (iv) promotion of sustainable production and better practices; and (v) increase access to financial incentives (Table 1). In this article, we concentrate on (i), (ii), (iii) and (v) since there is more evidence on their performance on the ground compared to (iv), and thus local actors have a clearer sense of their impacts on deforestation. 
Table 1. Interventions of REDD+ initiatives analyzed.

\begin{tabular}{|c|c|}
\hline Initiatives (Proponent) & Interventions \\
\hline $\begin{array}{l}\text { Transamazon (Amazon Environmental } \\
\text { Research Institute-IPAM) }\end{array}$ & $\begin{array}{l}\text { Household: PES *; management plans; alternative production } \\
\text { strategies *; capacity building; technical assistance; environmental } \\
\text { compliance; land tenure clarification through CAR * } \\
\text { Community: deforestation surveillance and in situ land use } \\
\text { monitoring *; strengthen organizations } \\
\text { No plan to sell credits }\end{array}$ \\
\hline $\begin{array}{l}\text { Sustainable Landscapes } \\
\text { (The Nature Conservancy-TNC) }\end{array}$ & $\begin{array}{l}\text { Household: land tenure clarification through CAR *; livelihood } \\
\text { alternatives *; capacity building; access to credit } \\
\text { Community: deforestation surveillance and in situ land use } \\
\text { monitoring *, sharing lessons } \\
\text { No plan to sell credits }\end{array}$ \\
\hline Cotriguaçu (Centro Vida Institute-ICV) & $\begin{array}{l}\text { Household: sustainable forest management (SFM)*; alternative } \\
\text { production strategies; land tenure clarification through CAR *; } \\
\text { capacity building; structuring municipal environmental } \\
\text { management; technology transfer; access to credit } \\
\text { Community: deforestation surveillance and in situ land } \\
\text { use monitoring * } \\
\text { No plan to sell credits }\end{array}$ \\
\hline SISA (State of Acre) & $\begin{array}{l}\text { Household: PES *, alternative production strategies *, } \\
\text { SFM, land tenure regularization through CAR * } \\
\text { Community: deforestation surveillance and in situ land } \\
\text { use monitoring * } \\
\text { Selling of credits still incipient }\end{array}$ \\
\hline $\begin{array}{l}\text { Bolsa Floresta (Amazonas Sustainable } \\
\text { Foundation-FAS) }\end{array}$ & $\begin{array}{l}\text { Household: PES *; income diversification *, capacity building } \\
\text { Community: deforestation surveillance and in situ land use } \\
\text { monitoring } * \text {, public services } * \\
\text { Selling of credits in some areas }\end{array}$ \\
\hline Jari (Biofílica/Jari) & $\begin{array}{l}\text { Household: technical assistance, sustainable production, SFM } \\
\text { Community: deforestation surveillance and in situ land } \\
\text { use monitoring * } \\
\text { Aims at selling credits }\end{array}$ \\
\hline
\end{tabular}

* interventions already being implemented.

\subsubsection{Monitoring and Land Clarification: Magic or Broken Sticks?}

Increasing surveillance and in situ monitoring through command and control measures has been at the heart of REDD+ interventions on the ground. We recognize the role of command and control interventions in reducing deforestation rates in the last decade [11,12,84]. However, there is also evidence that such approaches have social implications related to distributive equity (i.e., increased social inequalities among diverse local landholders) and social welfare (i.e., unequal distribution of income losses) that need to be considered in any structure that penalizes deforestation $[4,85]$. PPCDAm, for example, has been criticized for limiting its implementation to command and control measures [86-88]. Assunção et al. also show that centralized measures that treat the Brazilian Amazon as a largely uniform target have heterogeneous and spillover effects (i.e., negative behavioral adaptions that drive deforestation on the ground) [89]. Command and control does not normally affect large landowners [90], who are still responsible for the bulk of forest clearance in the Brazilian Amazon [15]. Furthermore, in some cases it has also increased migration to less monitored areas [85,88], which may cause leakage.

The Brazilian Environmental Protection Agency (IBAMA) is responsible for enforcing command and control measures. Field operations are based on past deforestation patterns and on satellite imagery. Coercion measures include the collection of administrative fines and in situ confiscation of produce and equipment whenever illegality is obvious [91]. IBAMA has received several critiques 
for being ineffective, but especially for corruption scandals involving large landholders [32,91,92]. Several authors have already demonstrated that although IBAMA is responsible for issuing the largest amount of fines in Brazil, the agency is known for its inefficiency in collecting them [90,91,93,94]. To make things worse, minor offenders (often smallholders), who do not want or cannot hire lawyers to challenge or disrupt administrative proceedings, are more likely to pay fines [90].

During the field research, we observed that local practices have already been developed to sabotage satellite monitoring and IBAMA fiscalization. An important example emerging from our qualitative data is the "método quebradão" (or "broken method" in English)—adopted in the state of Pará-where deforestation occurs without the use of fire and other techniques that can be identified via satellites or even in situ [95]. In this method, around $20 \%$ of the forest area is kept standing and just part of the forest is deforested either manually (in the case of smallholders) or with the use of poison sprayed in the tree canopy allowing them to die in different stages (in the case of large landholders). In this way, the forest "is broken," and the forested patches are not fully deforested, making monitoring by satellite images difficult $[88,96]$. Another important finding regards smallholders' perceptions of IBAMA fiscalization. For them, the national government should have been able to provide environmental education (i.e., knowledge sharing on climate change and adaptation actions) and capacity building (i.e., technical assistance on sustainable land use alternatives) before increasing command and control based enforcement. Historically, they have been actively encouraged to clear the forest as proof of "productive" activity under land-titling laws and for the acquisition of rural credits. It becomes almost utopic to expect that they will change their land use practices-mainly focused on growing food (i.e., cassava, fruits) for subsistence-without any assistance. In their words: "What does the government expect me to eat? The ball?", making reference to the 2014 World Cup, year when one of the field visits took place. Many of them responded in other tropes of resistance saying: "We will show the national government and REDD+ proponents who has the power by burning the forest in the next season if technical assistance does not come."

Knowledge about the spatial boundaries of landholdings has been improving since 2006, when CAR started to be implemented by different states in the Amazon. Due to the Forest Code of 2012, CAR is mandatory for all rural properties. Smallholders and other landholders, however, were not consulted or represented during the negotiations over the instrument. When it was initially designed, CAR aimed at linking forest tenure reform efforts with environmental compliance. In practice, however, CAR has become a tool to better monitor and control forest cover changes. CAR has a declaratory and permanent nature and contains specific information about the property (limits, environmental liability, land use). It does not per se clarify the ownership status of rural properties, neither does it guarantee that the landowners will follow the proper steps for environmental compliance. CAR information is under the responsibility of the declarant and the instrument has already been criticized for not having the registered data verified by government agencies [97] and for being unable to guarantee compliance [88]. Other critiques include: (i) the lack of strategy and coordination of the instrument with other policies and measures; (ii) an excessive focus on registration rather than the whole process of compliance; (iii) lack of priority given to CAR by the federal government; it took two years to be regulated and is far from being comprehensive enough; and (iv) the lack of attention to overarching strategic aspects such as level of public transparency, degree of overlapping polygons and systems automation routine $[88,89,97-100]$.

Finally, while analyzing qualitative data on local perceptions about CAR we found that they changed throughout the years from being a possible solution to the challenges of tenure clarification to becoming an undesirable tool that supports command and control measures. In addition, delays in its regulation at the national level and the recurrent prorogation of the deadline to registry properties has also meant that many landholders are starting to view CAR as possibly another policy measure that is not going to be effectively mandatory (or in their words, "is just on paper"). 
4.1.2. Payments for Ecosystems Services (PES) and Access to Financial Incentives: Digestive or Rotten Carrots?

Although much debated at the federal level, a national PES has not yet been established. The Forest Code authorizes the use of PES as a financial incentive, but it is not yet regulated at national level. The Bolsa Verde Program is a federal initiative that gives financial incentives to communities in conservation areas, but its main objective is to reduce poverty rather than to pay for environmental services. Famous for its visionary multi-dimensional aspects, the Bolsa Floresta Program is the main state-level PES initiative in Brazil. The program has achieved successful outcomes, such as increasing the wellbeing of households in different conservation units in the state of Amazonas [101]. But it has also suffered criticism for not allowing democratic and interactive processes of local participation [102,103]; not having different opportunity costs reflected in the payment structure [104]; possible lack of additionality [104-106]; and absence of non-compliance monitoring and conflict resolution tools [107]. Since 2010, SISA in the state of Acre has also been paying smallholders an annual bonus conditioned on the continued cessation of deforestation and burning according to the property management plan. Early evidence, however, has shown that payments are coming late or not at all, and farmers in the program areas are not receiving appropriate government support, which may result in decreased levels of participation [108]. The Transamazon initiative started implementing conditional payments in 2014, but there is no evidence yet of its outcomes. In the Bolsa Floresta Program, when asked about the direct payments being implemented, many smallholders affirmed they did not want money and instead complained: "We are prohibited from growing our own food, there is no management, authorities are distant and don't trust us. They can't just prohibit and pay; those who live in the communities need to work!".

Although recognizing that PES may play a key role in forest conservation in Brazil, Borner et al. [4,5] emphasize that PES implementation will face several limitations related to contract enforcement and unsecure and unclear tenure. The authors argue that the suspension of payments as a sanction of non-compliance becomes uncertain under imperfect enforcement. According to them, PES recipients facing a low enforcement probability may thus prefer to continue forest conversion and receive PES as an additional rent-and get away with it. It has been already acknowledged that, for various reasons, legal sanctions are seldom applied and enforcement is largely ignored because of the resistance such regulations encounter from individuals [98,109]. Indeed, as noted by different authors, the softening of restrictions on the amount of land that landholders are legally allowed to deforest under the Forest Code was a clear reflection of the lack of law enforcement in Brazil $[4,89,93,110-113]$. Other criticisms of PES initiatives in the Amazon include its limitations in terms of scope, outcomes and cost-effectiveness when compared to opportunity costs of actual land uses [103,114-117]. These are also reasons why some proponents of the initiatives analyzed here, such as the Sustainable Landscapes Program, opted to not include PES as a strategy for benefit-sharing.

How access to REDD+ financial incentives (i.e., ABC Program; local funds) other than PES will overcome problems of coordination with other opportunities that incentivize deforestation (i.e., rural credits) is still very unclear. At the local level, the most expressive example of a decentralized financial mechanism is the Surui Fund. Designed with high levels of local participation [118,119], the fund has been seen as an innovative way of decentralizing REDD+ fundraising and benefit-sharing while at the same time increasing autonomy [120]. The initiative, however, still presents some problems, such as absence of timely financial flows to meet the needs of the Surui tribe, principally of those who depend on productive activities, since the only currently accessible economic options in the reserve are environmentally damaging (i.e., illegal logging and cattle ranching) [121]. Divergences between members of the tribe and their different interests also generated some conflicts in relation to the fund and the REDD+ initiative as a whole [122].

At the national level, the Amazon Fund is the best example of a national results-based payment mechanism. The fund focuses on PPCDAm's main goals, such as monitoring and control, promotion of sustainable productive activities, land and territorial planning, as well as scientific 
and technological development. In line with federal conservation strategies, the fund has been prioritizing CAR implementation in its initiatives. It is hosted by the National Development Bank (BNDES) and proposals undergo routine procedures with bottlenecks in several stages of the process (i.e., no deadlines for analysis and disbursements). In addition, institutional characteristics of BNDES, one of the largest public investment banks funded by the Brazilian National Treasury, have generated some questions of legitimacy in the management of funds, once the bank is responsible for funding the main activities that cause the deforestation in the Amazon (i.e., large-scale hydroelectric dams; livestock and agriculture activities) [123].

Finally, outcomes of the ABC plan and its program are still very incipient. To qualify for a loan, farmers need to be registered under CAR. However, to date, the registry has faced several problems that create a barrier to financial access. Other limitations include producers' ignorance of the ABC plan, the low capacity of technology transfer, and the chronic deficiencies of the agricultural extension system in Brazil [124]. The ability of key actors to access credit is restricted by their lack of capacity and the uncertainty about the risks of new technologies. Furthermore, until recently, Banco do Brasil managers had no incentive to offer credits from the ABC plan because the provision of such credits was not factored into their performance review in the same way as the provision of other financial products, such as loans for livestock and agriculture.

\subsection{Subjects and Justifications: What do Rewards and Punishments Make Possible?}

This section asks two key questions: What processes of visibilization and articulation does the rewards and punishments discourse make possible? Or, in other words, what is hidden by it, what does it obscure from consideration and what kind of subject does it produce/assume? By answering these questions, we aim to shed some light on what is justifiable when it comes to REDD+ interventions and if the assumed subject is sufficiently realized for REDD+ to be effective.

The main technique of discipline and power used in the Amazon for REDD+ is spatial and, at the moment, is concentrated on increased monitoring and CAR implementation. The fact that CAR has been failing to promote environmental compliance and is serving just as another form of surveillance suggests that it has been transformed, and its old purposes are now obscured or even obliterated. Its function has become a way of exercising a more coordinated and therefore greater power that is realized at the expense of innumerable, more distributed forms of smaller powers. CAR also turns out to be a material technique to govern people on the ground. It seeks and enables control by creating the conditions for a more continuous and more comprehensive flow of information that registration under CAR makes possible. Interestingly, it requires an active acquiescence and support of the governed subjects (landowners). And, in some cases, it may even act as an incentive to increase deforestation, since registration under CAR facilitates the flow of bank loans, as also of subsidies for livestock and agriculture [121]. Recent analysis shows that at least two thirds of deforestation in the Amazon happened in areas that adhered to the CAR [125]. In other cases, CAR requires a relatively small proportion of the farm area to be maintained under forest cover, encouraging landowners with higher forest cover to undertake deforestation on their holdings for conversion towards agriculture. It shows how power works on and through the governed, as they are complicit in their "domination."

The fact that the collection of administrative fines imposed by IBAMA is ineffective and may affect only smallholders is a clear example of how power relations and hierarchies translate into heterogeneous practices of government. To understand a bit more of what was happening on the ground, we asked all participants of the qualitative research about the role of IBAMA in reducing deforestation. The majority (87\%) confirmed that command and control measures undertaken by IBAMA affect more smallholders than they do other actors. Many smallholders mentioned that IBAMA agents act like "vandals" and have been inspiring a culture of fear among smallholders that in turn feel constantly threatened. In their words: "The government sent violence before education. As some parents do with children: Beatings, beatings ... instead of educating." 
The implicit power relations that these techniques of coercive power promote is reflected in the fears of smallholders participating in the REDD+ initiatives analyzed here. Besides the fear of IBAMA, smallholders also fear unfulfilled promises (i.e., REDD+ initiative would fail to start or fail to continue; "REDD+ proponents talk too much and act too little"); displacement (i.e., fear of being reallocated or needing to migrate to other areas because of REDD+ initiative; "will REDD+ cause smallholders to lose land?"); and decrease in wellbeing and income (i.e., REDD+ initiative would fail to provide alternative sources of income; "stopping slash and burn practices had already harmed our incomes and diets"), to name a few (Table 2). Altogether, these fears have already been shown to restrict the power of innovation and adaptation of small producers in similar contexts [126].

Table 2. Challenges, hopes and fears of REDD+ initiatives identified by local actors in the REDD+ initiatives analyzed.

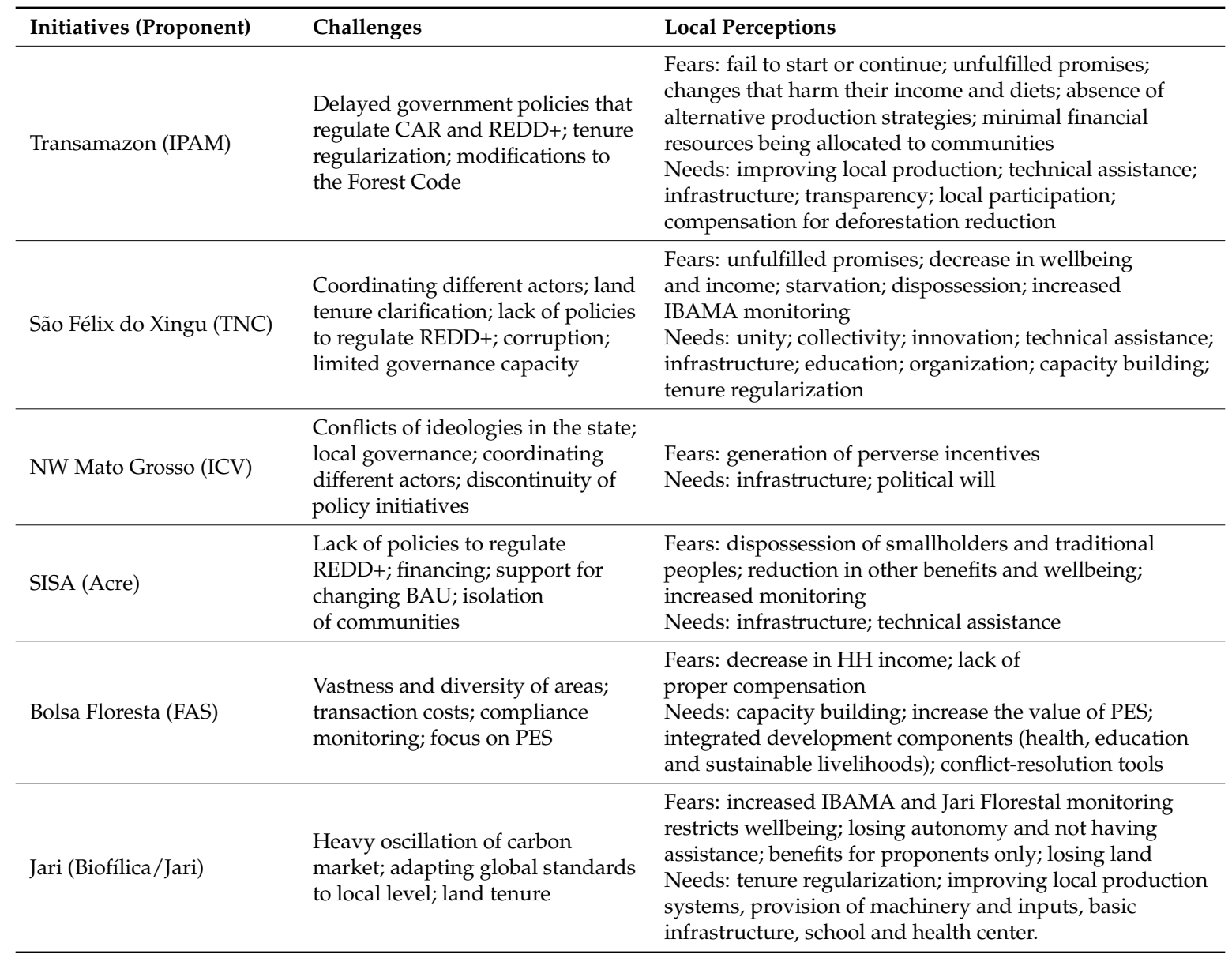

We observed during field research that consequences of this culture of fear include the migration of smallholders to other areas that are less controlled or to urban areas, as well as the disinterest of youth to remain in rural areas. The main actions that generate this culture reflect informal aspects of state practices that are neither accidental nor unusual, but rather correspond to what Olivier de Sardan calls "practical norms" of public agents [127]. This means that in practice there is a significant discrepancy between the law (formal rules) and the behavior of political elites and public officials (informal rules). Practical norms are part of the habits and practices of corrupt, bureaucratic and colonialist government agencies and their employees [128] and are embedded and institutionalized as social techniques of discipline, such as IBAMA's in situ monitoring and consequent punishments. REDD+ was supposed to provide an alternative to command and control measures and thereby overcome the limitations of such efforts. Instead, our findings show, REDD+ initiatives are incorporating past disciplinary forms 
of regulation, and reinscribing old practices of forest conservation (see also [31,129]). In smallholders' words: "increased monitoring just stop the smoke but do not solve the problem."

Local responses to techniques of governance, such as the "broken method," also demonstrate the complexities of behavioral changes in subjects that such techniques target. The fact that Amazon deforestation has increased in small increments, and most recently at a substantial rate [130], may be connected to such responses and behavioral adaptations and need to be considered so as to better understand the local dynamics influencing deforestation trends. In the case of the "broken method," resources, material goods and social hierarchies enabled innovation by forest managers, undermining the instrumental functionality of command and control measures. This suggests that the subjectivity and creativity of targeted smallholders and individuals are coming to surface, but with negative effects. It also shows creativity and innovation in behavioral choices, and the capacities of people to make use of the discretion that incentivization provides to subjects whose actions are to be regulated. Finding the right mix of interventions that speak to such intelligence on the ground is important to better understand the complexities of the relationships among human motivations, agent choices, and forest conservation. Expectations of strict obedience, for example, are widely recognized as lessening higher human capacities, such as independence and creativity and the ability to solve problems [131].

Most of the needs raised by local actors in the REDD+ initiatives we analyzed are related to capacity building, technical assistance and materials for alternative forms of production (Table 2). This leads to the question as to why policy discourses and practices around REDD+ have tended to focus more on rewards and punishments. The analysis suggests the discourse is both based on and is strengthening models of human and human-nature relations that prize cost-efficiency, are inattentive to complexity across targeted communities and individuals, ignore the possibility of changes in how people respond differently to material incentives, and underemphasize considerations of long-term outcomes of effectiveness and social justice. In this way, it may distract us from other measures that are equally or more effective when dealing with individual subjectivities. Table 2 demonstrates there is a diverse array of measures that address the main needs identified by smallholders-ignoring these expressions of needs raises the risks of undermining the long-term viability of REDD+. Indeed, evidence has already shown that long-term measures have effectively contributed to less damaging modifications of forest landscapes [102,132].

It is also important to recognize that PES and other rewards that frame conservation in economic terms based on techniques of remuneration may create a hierarchy within itself. From a "phatos of distance," to use Nietzsche's term, values are created by a discourse and put in to practice by a few privileged actors that are looking down on subjects and instruments [133].

This means, as Nietzsche put it, that the "pathos of distance [which] grows out of the ingrained difference between strata-when the ruling caste constantly looks afar and looks down upon subjects and instruments and just as constantly practices obedience and command, keeping down and keeping at a distance" [134]. And it is exactly this distance that reinforces the hierarchical relations between rulers and subjects. In the REDD+ carrots and sticks approach, smallholders are seen as "the poor", "the guilty" or, to better represent the discourse, "the donkey." As Pokorny et al. [31] argued, "market-oriented [initiatives] widely ignore local management practices, local ways of organizing work, and other local capacities and limitations". These approaches "demand that Amazonian rural dwellers adopt working routines and commitments which require attitudes that are essentially alien to their culture", the authors complement referring to externally defined models of development and conservation.

It has already been acknowledged that smallholders have the ability to adapt to the scarcity of natural resources in difficult conditions and without significant external support [117,119], as well as to respond to emerging production options and operate with comparatively low environmental costs [135-139]. In the rewards and punishments discourse, however, the subject is reduced to a mere instrument and has no capacity to be more connected and engaged in creative climate mitigation and adaptation solutions. At the same time, it allows certain actors (i.e., the payers, in the case of PES) 
to be granted an advantaged position by a way of repayment and compensation. It also assumes a stable and uniform relationship between cause and effect, which leads to an oversimplification of the complexities behind deforestation and may blur the importance of valuing individual capacities for climate adaptation and mitigation. Indeed, many smallholders in the different initiatives analyzed affirmed they do not want payments, they want to be trusted by, and work together with, governmental authorities and REDD+ proponents. In their view, they should not just be punished or rewarded; those who live in rural areas need to feel part of the process of reducing emissions by working on new solutions. This can be linked to Hegel's naturalistic approach to see human beings, in which he develops his conceptions of desire and recognition where the individual is known to use ways of intentional collaboration to be able to reach certain success for the collective, for, most of the time, this collaboration also benefits himself. The human being, in his view and for this reason, is a collective being [140].

It has already been pointed that the narrow definition of being (or "what it means to be human") as an individual guided only by self-interest and utility maximization is in conflict with the need to promote altruism and responsibility towards others and future generations. It is therefore in conflict with the notions of distributive justice [141,142]. The importance of individual and collective capacities, cultural attributes, rules and local institutions, as well as the creative and entrepreneurial capacity of the rural population have been recognized by sociologists [143,144], historians [145,146] and economists [136,147-149]. Instead of following Machiavellian and Hobbesian philosophies, perhaps is time to go back to Aristotelian ideas, in which every individual is also political and, as such, has to take responsibility for a common cause, such as fighting for our species survival.

Following the Aristotelian philosophy, happiness and wellbeing emerge through the performance of objective human activities. The latter can be seen in connection to the notion of human functioning developed by Sen and Nussbaum, both of whom stress the connection of this concept to Aristotle [150-152]. The aim is not the maximization of utility, but rather the training of dispositions that seek to find a middle ground between two extremes. In Aristotelian philosophy, virtue (or excellence) lies in achieving this middle ground. The emphasis is thus on harmony, rather than on maximization. The Aristotelian philosophy of human wellbeing points towards a conception of wellbeing in which a finite quantity of commodities does not prevent human development, since wellbeing springs from the harmonious use of existing commodities, rather than from the maximization of commodities possessed [153].

Foucault's later work on the "care of the self" constitutes a return to the Greek philosophy as he points out how one can govern oneself as an agent showing critique to be an important avenue for self-governance. Critique is then a matter of examining the status quo and maintaining the freedom to question it [154]. For Foucault, this freedom manifests and perpetuates itself through the Greek ancient practice called care of the self [155]. This concept remains a central theme in his analysis of the individual as subject to various power dynamics. Care of the self is lifelong work on one's body, mind, and soul, in order to better relate to other people and live an ethically driven life [155]. Foucault then, in his analysis of modes of power and care of the self, condones a full immersion into the present. In an age of mass consumerism and globalization, technological innovation and ecological consciousness, what constitutes individual identity has shifted, and discourses of power and truth have taken on new meanings [156]. Rewards and punishments approaches reflect these new meanings and place emphasis on human behavior being largely determined by incentives and penalties, sending different individuals in unanticipated directions.

There is also a contradiction in wanting to be perfectly cost-efficient in a situation whose nature is unpredictable, both because of the inherent dynamics and complexities of heterogeneous natural communities and assemblages, and related social-ecological interactions but also because of new forces and drivers such as climate change. The contradiction lies a little deeper than the mere conflict between the desire for financial efficiency and the outcome of behavior change. If we want to be cost-efficient, that is, achieving quick results with low costs, then we automatically want to be separated from the 
complexity of changing behavior, meaning that we forget what people are by concentrating on cheap and quick fixes to complex challenges. Yet, it is the very sense of separateness which makes us question the viability and justification of cost-efficient approaches for REDD+. To be cost-efficient means to isolate and fortify the financial aspects of REDD+, but it is exactly this isolation that distracts us from the urgent and important reasons of implementing REDD+, such as climate mitigation and adaptation. The rewards and punishments approach is also in conflict with the notions of distributive justice (i.e., focus on short-term outcomes) and it can be a very blunt and undiscriminating way of changing behavior-it can easily punish good and reward bad behavior (a critical example is the approval of the Brazilian Forest Code, which includes an amnesty for landowners who have previously deforested).

From the viewpoint of interviewed decision makers, REDD+ proponents and experts, changing the focus of interventions would not be difficult, especially under a favorable political scenario. Many answers indicated the necessity of incorporating measures focused on crop-livestock-forest integration and agroforestry systems in the REDD+ debate. These and other measures are under ABC plan goals but are still at the beginning stages of implementation. Other answers emphasized the need for an approach that engages different actors through an open-ended process, a pre-conditional state of engagement that can only exist when every actor holds a stake and has a voice and responsibilities. In this way, it is easier to address core motivations for collective behavior change [157]. A good example of interventions that encourage this collaborative state of engagement is demand-side measures, such as zero-deforestation cattle agreements signed by major meatpacking companies in the state of Pará (see [158]).

Finally, understanding persistence is increasingly important for testing policy measures and applying interventions on the ground $[159,160]$. Interventions have been shown "to crowd out intrinsic motivation if they are perceived as controlling - and to crowd in and thus increase intrinsic motivation if they are perceived as supportive" [64] (pp. 56-59, 71-72). Fortunately, there is a growing body of literature looking at what increases intrinsic motivation and how behavior change can be more persistent [66,161-167]. It is certainly time to strengthen the connections between the REDD+ debate and this literature.

\section{Conclusions}

REDD+ initiatives and national strategies can contribute to reducing deforestation and increasing the wellbeing of local people [168,169], as many of its proponents have suggested. But they can also foster social inequalities and run headlong into problems of governance and local resistances [170,171]. This article has undertaken a Foucault-inspired, close reading of the rewards and punishments discourse in relation to which REDD+ is situated to assess the nature and implications for REDD+ implementation in Brazil. We began with the fact that the prevalence of a rewards and punishments discourse as the context for REDD+ implementation necessarily normalizes and rationalizes some possibilities and forms of action, and excludes other considerations or ways of seeing and doing. The discursive dominance of rewards and punishments has real impacts in terms of the kinds of initiatives attempted, the forms of responses and adaptations to these interventions, and the outcomes that can be observed. The shortcomings and problems of interventions based on rewards and punishments approaches are particularly evident in the context of the complex, non-linear interactions of forests and people, the political dynamics of smallholders' responses, the heterogeneities and uncertainties related to targeted actors, and the evolving nature of deforestation trends in the Brazilian Amazon.

The intertwining of knowledge and power in the rewards and punishments discourse is a complex ensemble of social processes that can be better understood when broken into two main topics: (i) the limits of command and control measures for reducing deforestation, and (ii) the place of incentives as a decentralized and market-driven alternative to involve a broader range of private and public actors in the quest for low-cost climate mitigation alternatives. Flexibility and cost-efficiency are intertwined storylines articulated in climate negotiations, and the REDD+ frame as an opportunity to 
combine minimal-cost climate mitigation with sustainable forest management, biodiversity protection, poverty reduction and local socioeconomic development merged as a viable solution to international political negotiations. However, the local translations of international agreements around REDD+ need to come to better grips with the complexity of human selves and subjectivities at which Sen has hinted in his early criticisms of utility-maximization [172], and for which widespread evidence is now available in the work of many behavioral economists and evolutionary theorists who show that people's judgments and choices are a complex amalgam of intuitions [173], beliefs, norms, principles, dispositions, attitudes, emotions, passions and sentiments [66,174-178].

One of the central questions we aimed to answer while exploring the way in which the rewards and punishments approach has been used to legitimize techniques of governance in Brazil was: "What kind of subject does the rewards and punishments discourse produce/assume in practice?" This question is intimately linked to REDD+ because it leads directly to a consideration of the extent to which the techniques of remuneration and control, upon which rewards and punishments rely, are justifiable for REDD+. Following Foucault's ideas, it became clear that the rationalizations of state and other actors contain a particular conception of the subject that is to be governed. Each governmentality came with circumscribed expectations about the thoughts and behaviors of the incentivizable and controlled subject. The final conception of the human subject that emerges is that of the individual who acts out of self-interest, whose subjectivity is immutable over time, and whose behavior is predictably driven by techniques of coercion and remuneration. In such an approach, the malleability of subjectivity, the adaptive nature of individual and collective intelligence, and the complexity of mental and social calculations are either underplayed or ignored in favor of a simplified and simplistic model of the utility maximizer.

Our analysis provides insights about how the rewards and punishments discourse may be conditioning people into particular behavioral choices and adaptations, generating negative outcomes for deforestation, reducing positive feedbacks, and producing short-term unanticipated effects. Our results corroborate with previous research on rewards and punishments and their limits in changing behavior (see for example [173-178]). Our main argument is that exclusive attention to the conditions under which a rational system of rewards and punishments can be implemented to generate predictable forest protection outcomes in the Brazilian Amazon has led to the neglect of other ways of supporting smallholders that may in fact also help achieve the objectives of REDD+ interventions in the longer term. In this sense, one may even say that the recourse to REDD+ after a reliance on coercive techniques of forest protection is part of a process of trying to make reality match externally developed models, but its consequence is to distract attention away from trying to work with reality. Such a move profoundly constrains our understanding of human behavior and, more importantly, underestimates the capacity of smallholders to play a key role in climate mitigation and adaptation. The aptitude of smallholders in adopting a variety of practices is extraordinary. By ascribing a selfish nature to these actors, we move in the opposite direction of their ability to cooperate with each other, to create different solutions for their everyday problems, and to manage the gaps in conservation linked to remoteness and complexities of forest systems.

Our analysis and findings are less an argument in favor of doing away with rewards and punishments, and more an acknowledgement of the necessity of supplementing and moving beyond the pure calculus of efficiency and control encoded in arguments favoring rewards and punishments. Prioritizing REDD+ cost-efficiency and imposing a model based on such prioritization has the effect of ignoring the choices, selves and lives of smallholders, under-emphasizing the complexity and unpredictability of smallholder-forest-policy interactions, and leading to adverse long-term outcomes that support neither smallholder wellbeing nor climate mitigation.

It is also difficult to imagine how much of the remaining "residual" deforestation can be curbed through increased command and control and incentive-based approaches. Rather than being based on and deploying techniques of remuneration and coercion, REDD+ interventions should strive for a clearer understanding of the fundamental processes and practices that shape and drive deforestation 
vs conservation, such as the growing extra-local demand for forest and agricultural commodities, subsidies from outside the forest sector that encourage the production of such commodities, and the multifaceted and evolving nature of the subject targeted by incentives. Little attention focuses on the consumer, for example, in REDD+ debates. Measures associated with REDD+ interventions should reflect variations and changes in selves, social practices, and contexts. Instead of looking at smallholders as "donkeys" to be incentivized or controlled by carrots or sticks, we should embrace the idea that the current targets of forest policies are the ones most capable of creating sustainable solutions to problems of commodity provision and human survival under changing and challenging social and ecological conditions.

Acknowledgments: We are deeply grateful to all the smallholders who participated in our research for their patience and generosity in sharing their time and knowledge. REDD+ proponents and other local actors also played a key role in enabling this research. We also thank Rodrigo Calvet for his fruitful ideas. Finally, we thank the Centre for International Forestry Research for the collaboration and the opportunity of learning from REDD+ pilot initiatives.

Author Contributions: Maria Fernanda Gebara undertook the empirical and secondary data collection and analysis and coordinated the writing process. Arun Agrawal contributed to the writing by providing unique insights and by significantly helping in the alignment of theory, empirical evidence and conclusions.

Conflicts of Interest: The authors declare no conflict of interest.

\section{References}

1. Brukas, V.; Sallnäs, O. Forest management plan as a policy instrument: Carrot, stick or sermon? Land Use Policy 2012, 29, 605-613. [CrossRef]

2. Quartuch, M.R.; Beckley, T.M. Carrots and sticks: New Brunswick and Maine forest landowner perceptions toward incentives and regulations. Environ. Manag. 2014, 53, 202-218. [CrossRef] [PubMed]

3. Henderson, K.A.; Anand, M.; Bauch, C.T. Carrot or stick? Modelling how landowner behavioural responses can cause incentive-based forest governance to backfire. PLoS ONE 2013, 8, e77735. [CrossRef] [PubMed]

4. Börner, J.; Wunder, S.; Wertz-Kanounnikoff, S.; Nascimento, N. Forest law enforcement in the Brazilian Amazon: Costs and income effects. Glob. Environ. Chang. 2014, 29, 294-305. [CrossRef]

5. Börner, J.; Marinho, E.; Wunder, S. Mixing carrots and sticks to conserve forests in the Brazilian Amazon: A spatial probabilistic modeling approach. PLoS ONE 2015, 10, e0116846. [CrossRef] [PubMed]

6. Zwick, S.; Calderon, C. The Difficult Birth of Brazil's First “Green Municipality”. Ecosystem Marketplace. 2016. Available online: http:/ / www.ecosystemmarketplace.com/articles/paragominas-the-green-revolution-thatalmost-wasnt/ (accessed on 10 November 2016).

7. Silva-Chavez, G. The Missing Link in Protecting Forests? The Private Sector. Available online: http:/ / www.ecosystemmarketplace.com/articles/missing-link-protecting-forests-private-sector/ (accessed on 10 November 2016).

8. Foucault, M. Discipline and Punish: The Birth of the Prison; Vintage Books: New York, NY, USA, 1995.

9. Foucault, M. The subject and power. Crit. Inquiry 1982, 8, 777-795. [CrossRef]

10. De Sassi, C.; Sunderlin, W.D.; Sills, E.O.; Duchelle, A.E.; Ravikumar, A.; Resosudarmo, I.A.P.; Luttrell, C.; Joseph, S.; Herold, M.; Kweka, D.L.; et al. REDD+ on the ground: Global insights from local contexts. In REDD+ on the Ground: A Casebook of REDD+ Initiatives Across the Globe; Sills, E.O., Atmadja, S.S., De Sassi, C., Duchelle, A.E., Kweka, D.L., Resosudarmo, I.A.P., Sunderlin, W.D., Eds.; Center for International Forestry Research (CIFOR): Bogor, Indonesia, 2014.

11. Assunção, J.; Gandour, C.C.; Rocha, R. Deforestation Slowdown in the Legal Amazon: Prices or Policies? CPI Technical Report. NAPC/PUC-Rio: Rio de Janeiro, 2012. Available online: http:/ / climatepolicyinitiative. org/wp-content/uploads/2012/03/Deforestation-Prices-or-Policies-Working-Paper.pdf (accessed on 10 November 2016).

12. Assunção, J.; Gandour, C.; Rocha, R. Does Credit Affect Deforestation? Evidence from a Rural Credit Policy in the Brazilian Amazon. CPI/NAPC Working Paper. NAPC/PUC-Rio: Rio de Janeiro, 2012. Available online: http:/ / climatepolicyinitiative.org/wp-content/uploads/2013/01/Does-Credit-Affect-DeforestationEvidence-from-a-Rural-Credit-Policy-in-the-Brazilian-Amazon-Technical-Paper-English.pdf (accessed on 10 November 2016). 
13. Aubertin, C. Deforestation control policies in Brazil: Sovereignty versus the market. For. Trees Livelihoods 2015, 24, 147-162. [CrossRef]

14. Assunção, J.; Gandour, C.; Pessoa, P.; Rocha, R. Deforestation Scale and Farm Size: The Need for Tailoring Policy in Brazil; CPI Technical Report; NAPC/PUC-Rio: Rio de Janeiro, Brazil, 2015.

15. Godar, J.; Gardner, T.A.; Tizado, E.J.; Pacheco, P. Actor-specific contributions to the deforestation slowdown in the Brazilian Amazon. Proc. Natl. Acad. Sci. USA 2014, 111, 15591-15596. [CrossRef] [PubMed]

16. Bemelmans-Videc, M.L. Policy instrument choice and evaluation. In Carrots, Sticks and Sermons: Policy Instruments and Their Evaluation; Bemelmans-Videc, M.L., Rist, R.C., Vedung, E., Eds.; Transaction Publishers: New Brunswick, NJ, USA, 1998.

17. Foucault, M. The Archaeology of Knowledge; Routledge: London, UK; New York, NY, USA, 2002; p. 3.

18. Foucault, M. The History of Sexuality Volume 1: An Introduction; Allen Lane: London, UK, 1976.

19. Foucault, M. Truth and power. In Power/Knowledge: Selected Interviews and Other Writings 1972-1977; Gordon, C., Ed.; The Harvester Press: Brighton, UK, 1980; pp. 107-133.

20. Lessa, I. Discursive struggles within social welfare: Restaging teen motherhood. Br. J. Soc. Work 2006, 36, 283-298. [CrossRef]

21. Hardy, C.; Harley, B.; Phillips, N. Discourse analysis and content analysis: Two solitudes? Int. J. Qual. Methods 2004, 2, 19-22.

22. Foucault, M. The Birth of Biopolitics: Lectures at the Collège de France, 1978-1979; Palgrave Macmillan: Hampshire, UK, 2008; p. 269.

23. Maihofer, A. Geschlecht als Existenzweise; Helmer: Frankfurt, Germany, 1995.

24. Sauer, R.D. The political economy of gambling regulation. The political economy of gambling regulation. MDE Manag. Decis. Econ. 2001, 22, 1-3.

25. Luke, T. Ecocritique: Contesting the Politics of Nature, Economy, and Culture; University of Minnesota Press: Minneapolis, MN, USA, 1997.

26. Agrawal, A. Environmentality: Technologies of Government and Political Subjects; Duke University Press: Durham, NC, USA, 2005.

27. Fairhead, J.; Leach, M.; Scoones, I. Green grabbing: A new appropriation of nature? J. Peasant. Stud. 2012, 39, 253, 237-261. [CrossRef]

28. Pochmann, M. Qual Desenvolvimento? Oportunidades e Dificuldades do Brasil Contemporâneo; Boi Tempo: São Paulo, Brazil, 2009.

29. Cano, W. Power, Organization and Conflicts in Northern Bolivian Communities after Forest Governance Reforms. Ph.D. Thesis, Utrecht University, Utrecht, The Netherlands, 2012.

30. Medina, G.; Pokorny, B.; Campbell, B. Loggers and development agents exercising power over Amazonian villagers. Dev. Chang. Oxf. 2009, 40, 745-767. [CrossRef]

31. Pokorny, B.; Scholz, I.; de Jong, W. REDD+ for the poor or the poor for REDD+? About the limitations of environmental policies in the Amazon and the potential of achieving environmental goals through pro-poor policies. Ecol. Soc. 2013, 18, 3. [CrossRef]

32. May, P.H.; Millikan, B.; Gebara, M.F. The Context of REDD + in Brazil: Drivers, Agents, and Institutions, 2nd ed.; Center for International Forestry Research (CIFOR): Bogor, Indonesia, 2011.

33. Vedung, E. Policy instruments: Typologies and theories. In Carrots, Sticks and Sermons: Policy Instruments and Their Evaluation; Bemelmans-Videc, M.L., Rist, R.C., Vedung, E., Eds.; Transaction Publishers: New Brunswick, NJ, USA, 1998.

34. Bernard, L.L. Social Control in Its Sociological Aspects; Macmillan: New York, NY, USA, 1939.

35. Brigham, J.; Brown, D.W. Introduction. In Policy Implementation: Penalties or Incentives? Brigham, J., Brown, D.W., Eds.; Sage: Beverly Hills, CA, USA, 1980; pp. 7-77.

36. Turner, J.C.; Brown, R. Social status, cognitive alternatives and intergroup relations. In Differentiation between Social Groups: Studies in the Social Psychology or Intergroup Relations; Tajfel, H., Ed.; Academic Press: San Diego, CA, USA, 1978; pp. 201-234.

37. Machiavelli, N. ; Marriott, W.K., Translator; The Prince. 1908. Available online: https://www.gutenberg.org/ files/1232/1232-h/1232-h.htm (accessed on 10 November 2016).

38. Hardin, G. The tragedy of the commons. Science 1968, 162, 1243-1248. [CrossRef] [PubMed]

39. Ackerman, B.A.; Stewart, R.B. Reforming environmental law. Stanf. Law Rev. 1985, 37, 1333-1365. [CrossRef] 
40. Hahn, R.W.; Stavins, R.N. Economic incentives for environmental protection: Integrating theory and practice. Am. Econ. Rev. 1992, 82, 464-468.

41. Reitze, A.W., Jr. A century of pollution control: What's worked? What's failed? What might work? Environ. Law 1991, 21, 1549-1946.

42. Orts, E.W. Reflexive environmental law. Northwest Univ. L. Rev. 1995, 89, 1227-1340.

43. Sinclair, D. Self-regulation versus command and control? Beyond false dichotomies. L. Policy 1997, 19, 529-559. [CrossRef]

44. Gluck, P.; Rayner, J.; Cashore, B. Change in the governance of forest resources. In Forest in the Global Balance: Changing Paradigms; Mery, G., Alfaro, R., Kanninen, M., Labovikov, M., Eds.; World Series, 17; International Union of Forest Research Organizations: Helsinki, Finland, 2005; pp. 51-74.

45. Van Gossum, P.; Arts, B.; Verheyen, K. Smart regulation: Can policy instrument design solve forest policy aims of expansion and sustainability in Flanders and the Netherlands? For. Policy Econ. 2012, 16, $23-34$. [CrossRef]

46. Aldisert, L.; Helms, E.M.M. From command and control to coaching. IJBM 2000, 32, 36.

47. Holling, C.S.; Meffe, G.K. Command and control and the pathology of natural resource management. Conserv. Biol. 1996, 10, 328-337. [CrossRef]

48. UNFCC. Bali Action Plan. Decision 1/CP.13, FCCC/CP/2007/6/Add.1* (14 March 2008). Available online: http://unfccc.int/files/meetings/cop_13/application/pdf/cp_bali_action.pdf (accessed on 10 November 2016).

49. Marx, K. Capital: A Critique of Political Economy; Penguin Books: London, UK, 1992; Volume 1.

50. Locke, J. Second Treatise of Government. Early Modern Texts. 1689. Available online: http://www. earlymoderntexts.com/assets/pdfs/locke1689a.pdf (accessed on 15 January 2017).

51. Anderson, E. Value in Ethics and Economics; Harvard University Press: Cambridge, MA, USA, 1993; p. 208.

52. Sandel, M.J. What Money Can't Buy: The Moral Limits of Markets; Farrar, Strauss and Giroux: New York, NY, USA, 2012; p. 10.

53. Agrawal, A.; Gerber, E.; Chhatre, A. Motivational crowding in sustainable development interventions: Assessing the effects of multiple treatments. Am. Political Sci. Rev. 2015, 109, 470-487. [CrossRef]

54. Clot, S.; Andriamahefazafy, F.; Grolleau, G.; Ibanez, L.; Méral, P. Compensation and Rewards for Environmental Services (CRES) and efficient design of contracts in developing countries. Behavioral insights from a natural field experiment. Ecol. Econ. 2015, 113, 85-96. [CrossRef]

55. Sullivan, S. The Natural Capital Myth; or will Accounting Save the World? Preliminary Thoughts on Nature, Finance and Values. LCSV Working Paper Series No. 3; The Leverhulme Centre for the Study of Value: Manchester, UK, 2014. Available online: http:/ / thestudyofvalue.org/wp-content/uploads/2013/11/WP3Sullivan-2014-Natural-Capital-Myth.pdf (accessed on 15 January 2017).

56. Markandya, A. Economic Instruments: Accelerating the Move from Concepts to Practical Application. In Fourth Expert Group Meeting on Financial Issues of Agenda 21, Santiago, Chile, 8-10 January 1997. Available online: http://repositorio.cepal.org/bitstream/handle/11362/34312/S9700533_en.pdf.txt (accessed on 10 November 2016).

57. Huber, R.; Ruitenbeeck, J.; Da Motta, R. Market-Based Instruments for Environmental Policy Making, in Latin America and the Caribbean: Lessons from Eleven Countries; Report; World Bank: Washington, DC, USA, 1997.

58. Borregaard, N.; Sepúlveda, C. Introducing Economic Instruments at an Early Stage of Environmental Policy Making; North-South Center Miami: Santiago, Chile, 1998.

59. Martinez-Alier, J. The Environmentalism of the Poor: A Study of Ecological Conflicts and Valuation; Edward Elgar: Cheltenham, UK, 2002.

60. Goulder, L.H.; Kennedy, D. Valuing ecosystem services: Philosophical bases and empirical methods. In Nature's Services: Societal Dependence on Natural Ecosystems; Daily, G.C., Ed.; Island Press: Washington, DC, USA, 1997; pp. 23-47.

61. Nunes, P.A.L.D.; van den Bergh, J.C.J.M. Economic Valuation of Biodiversity: Sense or Nonsense. Ecol. Econ. 2001, 39, 203-222. [CrossRef]

62. McCauley, D.J. Selling out on nature. Nature 2006, 443, 27-28. [CrossRef] [PubMed]

63. O'Neill, J. Managing without prices: On the monetary valuation of biodiversity. Ambio 1997, 16, 56.

64. O'Neill, J. Markets and the environment: The solution is the problem. Econ. Political Wkly. 2001, 36, 1865-1873. 
65. Sagoff, M. On the economic value of ecosystem services. Environ. Values 2008, 17, 239-257. [CrossRef]

66. Neuteleers, S.; Engelen, B. Talking money: How market-based valuation can undermine environmental protection. Ecol. Econ. 2015, 117, 253-260. [CrossRef]

67. Frey, B.S.; Jegen, R. Motivation crowding theory. J. Econ. Surv. 2001, 15, 589-611. [CrossRef]

68. Bénabou, R.; Tirole, J. Incentives and prosocial behavior. Am. Econ. Rev. 2006, 96, 1652-1678. [CrossRef]

69. Gneezy, U.; Meier, S.; Rey-Biel, P. When and why incentives (don't) work to modify behavior. J. Econ. Perspect. 2011, 25, 191-210. [CrossRef]

70. Sills, E.O.; Atmadja, S.S.; de Sassi, C.; Duchelle, A.E.; Kweka, D.L.; Resosudarmo, I.A.P.; Sunderlin, W.D. (Eds.) REDD+ on the Ground: A Casebook of REDD+ Initiatives Across the Globe; Center for International Forestry Research (CIFOR): Bogor, Indonesia, 2014.

71. Sunderlin, W.D.; Larson, A.M.; Duchelle, A.E.; Sills, E.O.; Luttrell, C.; Jagger, P.; Pattanayak, S.; Cronkleton, P.; Ekaputri, A.; de Sassi, C.; et al. Technical Guidelines for Research on REDD+ Subnational Initiatives, 2nd ed.; Center for International Forestry Research (CIFOR): Bogor, Indonesia, 2014.

72. Ryan, G.W.; Bernard, H.R. Techniques to identify themes. Field Methods 2003, 15, 85-109. [CrossRef]

73. Instituto Nacional De Pesquisas Espaciais (INPE). Monitoramento da Cobertura Florestal da Amazônia por Satélites: Sistemas PRODES, DETER, DEGRAD-2004-2015; INPE: São José dos Campos, Brazil, 2015.

74. Ministério do Meio Ambiente (MMA). Estrategia Nacional de REDD+; Portaria n. 370 de 2 de Dezembro de 2015; Federal Government of Brazil: Brasília, Brazil, 2015.

75. Chhatre, A.; Lakhanpal, S.; Larson, A.M.; Nelson, F.; Ojha, H.; Rao, J. Social safeguards and co-benefits in REDD+: A review of the adjacent possible. Curr. Opin. Environ. Sustain. 2012, 4, 654-660. [CrossRef]

76. Ghazoul, J.; Butler, R.; Mateo-Vega, J.; Koh, L.P. REDD: A reckoning of environmental and development implications. Trends Ecol. Evol. 2010, 25, 396-402. [CrossRef] [PubMed]

77. Vijge, M.J.; Brockhaus, M.; Di Gregorio, M.; Muharrom, E. Framing National REDD+ Benefits, Monitoring, Governance and Finance: A Comparative Analysis of Seven Countries; Center for International Forestry Research (CIFOR): Bogor, Indonesia, 2016.

78. Ministério do Meio Ambiente. Summary of Information on How the Cancun Safeguards were Addressed and Respected by Brazil throughout the Implementation of Actions to Reduce Emissions from Deforestation in the Amazon Biome between 2006 and 2010; Ministério do Meio Ambiente: Brasilia, Brazil, 2015.

79. May, P.H.; Gebara, M.F.; de Barcellos, L.M.; Rizek, M.B.; Millikan, B. The Context of REDD+ in Brazil: Drivers, Agents, and Institutions, 3rd ed.; CIFOR Occasional Paper No. 160; Center for International Forestry Research (CIFOR): Bogor, Indonesia, 2016.

80. Gebara, M.F.; Thuault, A. GHG Mitigation in Brazil's Land Use Sector: An Introduction to the Current National Policy Landscape; Working Paper; World Resources Institute: Washington, DC, USA, 2013. Available online: http:/ / wri.org/publication/ghg-mitigation-brazil-land-use-sector (accessed on 24 February 2017).

81. Observatório do Clima. Organizações da Sociedade Civil Voltam a Criticar Política Nacional de Mudanças Climáticas. Observatório do Clima, 2013. Available online: http://www.observatoriodoclima.eco.br/ organizacoes-da-sociedade-civil-voltam-a-criticar-politica-nacional-de-mudancas-climaticas / (accessed on 24 February 2017).

82. Observatório do Clima. Nota do Observatório do Clima sobre a Estratégia Nacional de REDD+. Observatório do Clima, 2015. Available online: http:/ / www.observatoriodoclima.eco.br/nota-do-observatorio-do-climasobre-a-estrategia-nacional-de-redd/ (accessed on 24 February 2017).

83. Observatório do Clima. Especialistas do OC Questionam Decreto Que Cria Comissão Nacional de REDD+. Observatório do Clima, 2015. Available online: http:/ / www.observatoriodoclima.eco.br/especialistas-dooc-questionam-decreto-que-cria-comissao-nacional-de-redd/ (accessed on 24 February 2017).

84. Hargrave, J.; Kis-Katos, K. Economic causes of deforestation in the Brazilian Amazon: A panel data analysis for the 2000s. ERE 2013, 54, 471-494. [CrossRef]

85. Gebara, M.F. Sustainable landscapes program in São Felix do Xingu. In REDD+ on the Ground: A Casebook of REDD+ Initiatives Across the Globe; Sills, E.O., Atmadja, S.S., De Sassi, C., Duchelle, A.E., Kweka, D.L., Resosudarmo, I.A.P., Sunderlin, W.D., Eds.; Center for International Forestry Research (CIFOR): Bogor, Indonesia, 2014.

86. Abdala, G.C.; Reis Rosa, M. PPCDam: Avaliação 2004-2007; Revisão 2008; Ministério do Meio Ambiente: Brasília, Brazil, 2008. 
87. Maia, H.; Hargrave, J.; Goméz, J.J.; Roper, M. Avaliação do Plano de Ação Para a Prevenção e Controlo do Desmatamento da Amazônia Legal-PPCDAm-2007-2010; Economic Commission for Latin America and the Caribbean (CEPAL), Institute of Economic and Applied Research (IPEA), German Society for International Cooperation (GIZ): Brasilia, Brazil, 2011.

88. Gebara, M.F. Governança de Paisagens Florestais: Impactos Sociais da Bricolagem Institucional em São Félix do Xingu. Ph.D. Thesis, Federal Rural University of Rio de Janeiro, 2015. Available online: http:/ / r1.ufrrj.br/cpda/wp-content/uploads/2015/05/Governança-de-Paisagens-Florestais-ImpactosSociais-da-Bricolagem-Institucional-em-S ao-Félix-do-Xingu.pdf (accessed on 10 November 2016).

89. Assunção, J.; Gandour, C.; Pessoa, P.; Rocha, R. Deforestation Scale and Farm Size: The Need for Tailoring Policy in Brazil. CPI Technical Report. NAPC/PUC-Rio: Rio de Janeiro, 2015. Available online: https:/ / climatepolicyinitiative.org/wp-content/uploads/2015/08/Deforestation-Scale-and-FarmSize-the-Need-for-Tailoring-Policy-in-Brazil----Technical-Paper.pdf (accessed on 10 November 2016).

90. Telles do Valle, R.S. Saindo do Quadrado: Propostas Para Tentar Dinamizar o Mercado de Cotas de Reserva Ambiental; Instituto Sócio-Ambiental: Brasília, Brazil, 2013.

91. Brito, B.; Barreto, P. A eficácia da aplicação da lei de crimes ambientais pelo lbama para proteção de florestas no Pará. Rev. Direito Ambient. 2006, 43, 35-65.

92. Moura, D.G. Mídia e Corrupção: A Operação Curupira na Amazônia. Universidade de Brasília, Centro de Desenvolvimento Sustentável: Brasilia, Brazil, 2006; p. 147. Available online: https://core.ac.uk/download/ files/610/16343809.pdf (accessed on 10 November 2016).

93. Hirakuri, S.R. Can Law Save the Forests? Lessons from Finland and Brazil; Center for International Forestry Research (CIFOR): Bogor, Indonesia, 2003.

94. Brito, B. Multas Pós-Operação Curupira no Mato Grosso; Boletim “O Estado da Amazônia”; IMAZON: Belém, Brazil, 2009.

95. Barros, C.; Barcelos, L. Crime e Grilagem Com Uso do CAR. Publica, 2016. Available online: http: / /apublica. org/2016/08/crime-e-grilagem-com-uso-do-car (accessed on 15 January 2017).

96. Vieira, I.; Veiga, J.; Aguiar, A.; Gavina, J. O Papel da Pecuária na Evolução da Fronteira: Relatório Geoma; Embrapa: São Paulo, Brazil, 2010.

97. Camargo, F. CAR Para "Inglês Ver"; Instituto Sócio-Ambiental: Brasília, Brazil, 2014. Available online: http://www.socioambiental.org/pt-br/blog/blog-do-ppds/car-para-ingles-ver (accessed on 10 November 2016).

98. Pires, M.O.; Ortega, V.G. O Cadastro Ambiental Rural na Amazônia; Conservação Internacional: Brasília, Brazil, 2013.

99. Telles do Valle, R.S. CAR Pra Q; Instituto Sócio-Ambiental: Brasília, Brazil, 2014. Available online: http://www.socioambiental.org/pt-br/blog/blog-do-ppds/car-para-que (accessed on 10 November 2016).

100. Azevedo, A.; Rajão, L.R.; Costa, M.; Stabile, M.C.C.; Alencar, A.; Moutinho, P. Cadastro ambiental rural e sua influência na dinâmica do desmatamento na Amazônia Legal. Bol. Amazôn. Pauta 2014, 3, 3-16.

101. Börner, J.; Wunder, S.; Reimer, F.; Bakkegaard, R.K.; Viana, V.; Tezza, J.; Pinto, T.; Lima, L.; Marostica, S. Promoting Forest Stewardship in the Bolsa Floresta Programme: Local Livelihood Strategies and Preliminary Impacts; Center for International Forestry Research (CIFOR): Rio de Janeiro, Brazil; Fundação Amazonas Sustentável (FAS): Manaus, Brazil; Entwicklungsforschung (ZEF), University of Bonn: Zentrum für Bonn, Germany, 2013; p. 70.

102. Gebara, M.F. Importance of local participation in achieving equity in benefit-sharing mechanisms for REDD+: A case study from the Juma Sustainable Development Reserve. IJC 2013, 7, 473-497. [CrossRef]

103. Vatn, A.; Kajembe, G.; Leiva-Montoya, R.; Mosi, E.; Nantongo, M.; Silayo, D.A. Instituting REDD+: An Analysis of the Processes and Outcomes of Two Pilot Projects in Brazil and Tanzania; IIED: London, UK, 2013.

104. Newton, P.; Nichols, E.S.; Endo, W.; Peres, C.A. Consequences of actor level livelihood heterogeneity for additionality in a tropical forest payment for environmental services programme with an undifferentiated reward structure. Glob. Environ. Chang. 2012, 1, 127-136. [CrossRef]

105. Pereira, S.N.C. Payment for environmental services in the Amazon Forest: How can conservation and development be reconciled? JED 2010, 19, 171. [CrossRef]

106. Elfving, M. Payment for Environmental Services: A Tool for Forest Conservation and Empowerment of the Local People in the State of Amazonas, Brazil? A Case Study of Programa Bolsa Floresta. Bachelor's Thesis, Peace and Development Studies, Linnaeus University, Växjö, Sweden, 2010; p. 96. 
107. Agustsson, K.; Garibjana, A.; Rojas, E.; Vatn, A. An assessment of the Forest Allowance Programme in the Juma Sustainable Development Reserve in Brazil. Int. For. Rev. 2014, 16, 87-102. [CrossRef]

108. Duchelle, A.E.; Cromberg, M.; Gebara, M.F.; Guerra, R.; Melo, T.; Larson, A.; Cronkleton, P.; Börner, J.; Sills, E.; Wunder, S.; et al. Linking forest tenure reform, environmental compliance, and incentives: Lessons from REDD+ initiatives in the Brazilian Amazon. World Dev. 2014, 55, 53-67. [CrossRef]

109. Vedung, E.; van der Doelen, C.J. The sermon: Information programs in the public policy process-Choice, effects, and evaluation. In Carrots, Sticks and Sermons: Policy Instruments and Their Evaluation; Bemelmans-Videc, M.L., Rist, R.C., Vedung, E., Eds.; Transaction Publishers: New Brunswick, NJ, USA, 1998; pp. 103-128.

110. Martin, S. Potenciais Impactos das Alterações do Código Florestal Brasileiro na Meta Nacional de Redução de Emissões de Gases de Efeito Estufa; Fundação Getulio Vargas, Observatório do Clima: São Paulo, Brazil, 2010.

111. Metzger, J.P. O código florestal tem base científica? Nat. Conserv. 2010, 8, 92-99. [CrossRef]

112. Barreto, P.; Ellinger, P. Código Florestal: Como Sair do Impasse? Imazon: Belém, Brazil, 2011.

113. Telles do Valle, R.S. Lento Adeus ao Código Florestal; Instituto Sócio-Ambiental: Brasília, Brazil, 2012. Available online: https://www.socioambiental.org/pt-br/blog/blog-do-isa/lento-adeus-ao-codigoflorestal (accessed on 10 November 2016).

114. Hall, A. Better RED than dead: Paying the people for environmental services in Amazonia. Philos. Trans. R. Soc. Lond. 2008, 363, 1925-1932. [CrossRef] [PubMed]

115. Bartels, W. Participatory Land Use Planning in the Brazilian Amazon: Creating Learning Networks among Farmers, Non-Governmental Organizations, and Government Institutions; School of Natural Resources and Environment, University of Florida: Gainesville, FL, USA, 2009; p. 167.

116. Börner, J.; Wunder, S.; Wertz-Kanounnikoff, S.; Tito, M.R.; Pereira, L.; Nascimento, N. Direct conservation payments in the Brazilian Amazon: Scope and equity implications. Ecol. Econ. 2010, 69, 1272-1282. [CrossRef]

117. Pokorny, B.; Jong, W.; Godar, J.; Pacheco, P.; Johnson, J. From large to small: Reorienting rural development policies in response to climate change, food security and poverty. For. Policy Econ. 2013, 36, 52-59. [CrossRef]

118. Equipe de Conservação da Amazoônia (ECAM). Free, Prior and Informed Consent. Surui Carbon Project; ACT Brazil: Brasilia, Brazil, 2010.

119. Fundo Brasileiro para Biodiversidade (Funbio). Fundo Paiter Surui: Manual Operacional; Funbio: Rio de Janeiro, Brazil, 2013.

120. West, T.A.P. Indigenous community benefits from a de-centralized approach to REDD+ in Brazil. Clim. Policy 2015, 1, 1469-3062. [CrossRef]

121. Gebara, M.F.; Muccillo, L.; May, P.; Vitel, C.; Loft, L.; Santos, A. Lessons from Local Environmental Funds for REDD+ Benefit Sharing with Indigenous People in Brazil; Center for International Forestry Research (CIFOR): Bogor, Indonesia, 2014.

122. Lang, C. Leaders of the Paiter Suruí Ask that the Carbon Project with Natura be Terminated. REDD+ Monitor, 2015. Available online: http:/ / www.redd-monitor.org/2015/01/13/leaders-of-the-paiter-surui-ask-thatthe-carbon-project-with-natura-be-terminated/ (accessed on 10 November 2016).

123. Marcovitch, J.; Cuzziol Pinsky, V. Amazon Fund: Financing deforestation avoidance. Rev. Adm. 2014, 49, 2. [CrossRef]

124. Observatório do ABC. Propostas Para Revisão do Plano ABC. Fundação Getulio Vargas: São Paulo, Brazil, 2015. Available online: http://mediadrawer.gvces.com.br/abc/original/gv-agro_em-simples.pdf (accessed on 10 November 2016).

125. Observatório do ABC. Aumento do Desmatamento na Amazônia Legal Está Ligado à Agropecuária. Available online: http:/ /observatorioabc.com.br/2016/12/aumento-do-desmatamento-na-amazonia-legalesta-ligado-agropecuaria/ (accessed on 24 February 2017).

126. De Koning, J. Unpredictable outcomes in forestry-Governance institutions in practice. Soc. Nat. Resour. 2014, 27, 358-371. [CrossRef]

127. Olivier de Sardan, J.P. The delivery state in Africa: Interface bureaucrats, professional cultures and the bureaucratic mode of governance. In States at Work: The Dynamics of African Bureaucracies; Olivier De Sardan, J.P., Bierschenk, T., Eds.; Bill: Boston, MA, USA, 2014; pp. 399-430.

128. Bourdieu, P. The Logic of Practice; Stanford University Press: Stanford, CA, USA, 1990.

129. Angelsen, A.; Brockhaus, M.; Sunderlin, W.D.; Verchot, L.V. (Eds.) Analysing REDD+: Challenges and Choices; Center for International Forestry Research (CIFOR): Bogor, Indonesia, 2012. 
130. Schiffman, R. Brazil's Deforestation Rates Are on the Rise Again. Newsweek. 2015. Available online: http:/ / www.newsweek.com/2015/04/03/brazils-deforestation-rates-are-rise-again-315648.html (accessed on 15 January 2017).

131. Dix, G. Governing by Carrot and Stick. A Genealogy of the Incentive. Ph.D. Thesis, University of Amsterdam, Amsterdam, The Netherlands, 2014. Available online: http:/ /hdl.handle.net/11245/1.417336 (accessed on 10 November 2016).

132. Kuyvenhoven, A. Creating an enabling environment: Policy conditions for less-favored areas. Food Policy 2004, 29, 407-429. [CrossRef]

133. Nietzsche, F.W. On the Genealogy of Morals; Vintage Books: New York, NY, USA, 1989.

134. Nietzsche, F. Beyond Good and Evil: Prelude to a Philosophy of the Future; Hollingdale, R.J., Ed.; Penguin Books: London, UK, 1973; p. 257.

135. Lambin, E.F.; Meyfroidt, P. Land use transitions: Socio-ecological feedback versus socio-economic change. Land Use Policy 2010, 27, 108-118. [CrossRef]

136. Biggs, S. A multiple source of innovation model of agricultural research and technology promotion. World Dev. 1990, 18, 1481-1499. [CrossRef]

137. Fearnside, P.M. Deforestation in Brazilian Amazonia: History, rates, and consequences. Conserv. Biol. 2005, 19, 680-688. [CrossRef]

138. Ostrom, E. Governing the Commons: The Evolution of Institutions for Collective Action; Cambridge University Press: Cambridge, UK, 1990.

139. Pacheco, P. Agrarian reform in the Brazilian Amazon: Its implications for land distribution and deforestation. World Dev. 2009, 37, 1337-1347. [CrossRef]

140. Hegel, G.W.F. Phenomenology of Spirit; Miller, A.V., Translator; Oxford University Press: Oxford, UK, 1977.

141. Bina, O.; La Camera, F. Promise and shortcomings of a green turn in recent policy responses to the "double crisis". Ecol. Econ. 2011, 70, 2308-2316. [CrossRef]

142. Pelletier, N. Environmental sustainability as the first principle of distributive justice: Towards an ecological communitarian normative foundation for ecological economics. Ecol. Econ. 2010, 69, 1887-1894. [CrossRef]

143. Fukuyama, F. The Social Virtues and the Creation of Prosperity; Penguin Books: London, UK, 1995.

144. Putman, R. Making Democracy Work; Princeton University Press: Princeton, NJ, USA, 1993.

145. Landes, D.S. The Wealth and Poverty of Nations; W.W. Norton \& Co.: New York, NY, USA, 1998.

146. North, D.C. Institutions, Institutional Change and Economic Performance; Cambridge University Press: Cambridge, UK, 1990.

147. Arrow, K.J. The Limits of Organization; Norton \& Co.: New York, NY, USA, 1974.

148. Guiso, L.; Sapienza, P.; Zingales, L. Does culture affect economic outcome? J. Econ. Perspect. 2006, $20,23-48$. [CrossRef]

149. Lewis, A. The Theory of Economic Growth; George Allen \& Unwin: London, UK, 1955.

150. Sen, A.K. Development as Freedom; Oxford University Press: Oxford, UK, 1999.

151. Nussbaum, M.C. Human functioning and social justice: In defense of Aristotelian essentialism. Political Theory 1992, 20, 202-246. [CrossRef]

152. Nussbaum, M. Women and Human Development: The Capabilities Approach; Cambridge University Press: Cambridge, UK, 2000.

153. Martins, N.O. Ecosystems, strong sustainability and the classical circular economy. Ecol. Econ. 2016, 129, 32-39. [CrossRef]

154. Foucault, M. What is critique? In The Essential Foucault; The New Press: New York, NU, USA, 1997; pp. 263-278.

155. Foucault, M. The ethics of the concern of the self as a practice of freedom. In Ethics: Subjectivity and Truth; The New Press: New York, NY, USA, 1997; pp. 281-301.

156. Batters, S.M. Care of the Self and the Will to Freedom: Michel Foucault, Critique and Ethics; Senior Honors Projects. Paper 231; University of Rhode Island: Kingston, RI, USA, 2011.

157. Van Vugt, M. Averting the tragedy of the commons: Using social psychological science to protect the environment. Curr. Dir. Psychol. Sci. 2009, 18, 169-173. [CrossRef]

158. Gibbs, H.K.; Munger, J.; L’Roe, J.; Barreto, P.; Pereira, R.; Christie, M.; Amaral, T.; Walker, N.F. Did ranchers and slaughterhouses respond to zero-deforestation agreements in the Brazilian Amazon? Conserv. Lett. 2016, 9, 32-42. [CrossRef] 
159. Thaler, R.H.; Sunstein, C. Nudge: Improving Decisions about Health, Wealth and Happiness; Penguin Books: New York, NY, USA, 2009.

160. Karki, S.T.; Hubacek, K. Developing a conceptual framework for the attitude-intention- behaviour links driving illegal resource extraction in Bardia National Park, Nepal. Ecol. Econ. 2015, 117, 129-139. [CrossRef]

161. Frey, E.; Rogers, T. Persistence: How Treatment Effects Persist after Interventions Stop. Policy Insights Behav. Brain Sci. 2014, 1, 172-179. [CrossRef]

162. Blasch, J.; Ohndorf, M. Altruism, moral norms and social approval: Joint determinants of individual offset behavior. Ecol. Econ. 2015, 116, 251-260. [CrossRef]

163. Kilgore, M.A.; Snyder, S.A.; Eryilmaz, D.; Markowski-Lindsay, M.A.; Butler, B.R.; Kittredge, D.B.; Catanzaro, P.F.; Hewes, J.H.; Andrejczyk, K. Assessing the relationship between different forms of landowner assistance and family forest owner behaviors and intentions. J. For. 2015, 113, 12-19. [CrossRef]

164. Bolderdijk, J.W.; Steg, L.; Geller, E.S.; Lehman, P.K.; Postmes, T. Comparing the effectiveness of monetary versus moral motives in environmental campaigning. Nat. Clim. Chang. 2013, 3, 413-416. [CrossRef]

165. Van der Linden, S. Intrinsic motivation and pro-environmental behavior. Nat. Clim. Chang. 2015, 5, 612-613. [CrossRef]

166. Clayton, S.; Devine-Wright, P.; Stern, P.C.; Whitmarsh, L.; Amanda Carrico, A.; Steg, L.; Swim, J.; Bonnes, M. Psychological research and global climate change. Nat. Clim. Chang. 2015, 5, 640-646. [CrossRef]

167. Matulis, B.S. Valuing nature: A reply to Esteve Corbera. Ecol. Econ. 2015, 110, 158-160. [CrossRef]

168. Hoang, M.; Do, T.; Pham, M.; van Noordwijk, M.; Minang, P.A. Benefit distribution across scales to reduce emissions from deforestation and forest degradation (REDD+) in Vietnam. Land Use Policy 2013, 31, 48-60. [CrossRef]

169. Maraseni, T.N.; Neupane, P.R.; Lopez-Casero, F.; Cadman, T. An Assessment of the Impacts of the REDD+ Pilot Project on Community Forests User Groups (CFUGs) and their Community Forests in Nepal. J. Environ. Manag. 2014, 136, 37-46. [CrossRef] [PubMed]

170. Dokken, T.; Putri, A.A.D.; Kweka, D.L. Making REDD+ Work for Communities and Forest Conservation in Tanzania. In REDD+ on the Ground: A Casebook of REDD+ Initiatives Across the Globe; Sills, E.O., Atmadja, S.S., De Sassi, C., Duchelle, A.E., Kweka, D.L., Resosudarmo, I.A.P., Sunderlin, W.D., Eds.; Center for International Forestry Research (CIFOR): Bogor, Indonesia, 2014.

171. Leggett, M.; Lovell, H. Community Perceptions of REDD+: A Case Study from Papua New Guinea. Clim. Policy 2012, 12, 115-134. [CrossRef]

172. Sen, A. Rational fools: A critique of the behavioral foundations of economic theory. Philos. Public Aff. 1977, 6, 317-344.

173. Haidt, J.; Joseph, C. Intuitive ethics: How innately prepared intuitions generate culturally variable virtues. Daedalus 2004, 133, 55-66. [CrossRef]

174. Geller, E.S. The challenge of increasing proenvironmental behavior. In Handbook of Environmental Psychology; Bechtel, R.B., Churchman, A., Eds.; Wiley: New York, NY, USA, 2002; pp. 525-540.

175. Geller, E.S.; Winett, R.A.; Everett, P.B. Preserving the Environment: New Strategies for Behavior Change; Pergamon: Elmsford, NY, USA, 1982.

176. Gärling, T.; Loukopoulos, P. Effectiveness, public acceptance, and political feasibility of coercive measures for reducing car traffic. In Threats to the Quality of Urban Life from Car Traffic: Problems, Causes, and Solutions; Gärling, T., Steg, L., Eds.; Elsevier: Amsterdam, The Netherlands, 2007; pp. 313-324.

177. Gärling, T.; Schuitema, G. Travel demand management targeting reduced private car use: Effectiveness, public acceptability and political feasibility. J. Soc. Issues 2007, 63, 139-153. [CrossRef]

178. Steg, L.; Dreijerink, L.; Abrahamse, W. Why are energy policies acceptable and effective? Environ. Behav. 2006, 38, 92-111. [CrossRef]

(C) 2017 by the authors. Licensee MDPI, Basel, Switzerland. This article is an open access article distributed under the terms and conditions of the Creative Commons Attribution (CC BY) license (http:/ / creativecommons.org/licenses/by/4.0/). 